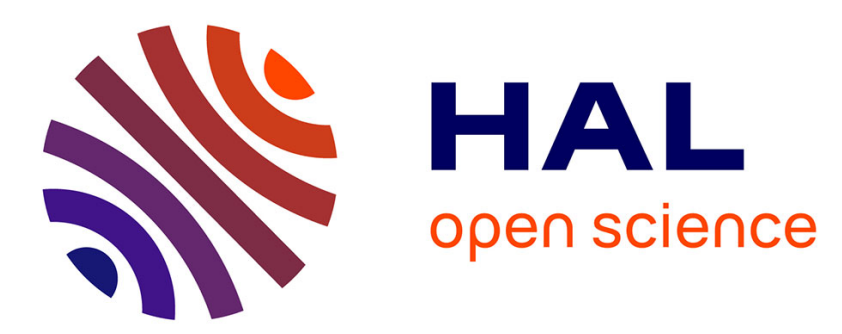

\title{
Textural and Compositional Changes in the Lithospheric Mantle Atop the Hawaiian Plume: Consequences for Seismic Properties
}

Andrea Tommasi, Lucan Mameri, Marguerite Godard

\section{- To cite this version:}

Andrea Tommasi, Lucan Mameri, Marguerite Godard. Textural and Compositional Changes in the Lithospheric Mantle Atop the Hawaiian Plume: Consequences for Seismic Properties. Geochemistry, Geophysics, Geosystems, 2020, 10.1029/2020GC009138 . hal-02944378

\section{HAL Id: hal-02944378 \\ https://hal.umontpellier.fr/hal-02944378}

Submitted on 21 Sep 2020

HAL is a multi-disciplinary open access archive for the deposit and dissemination of scientific research documents, whether they are published or not. The documents may come from teaching and research institutions in France or abroad, or from public or private research centers.
L'archive ouverte pluridisciplinaire HAL, est destinée au dépôt et à la diffusion de documents scientifiques de niveau recherche, publiés ou non, émanant des établissements d'enseignement et de recherche français ou étrangers, des laboratoires publics ou privés. 
Key Points:

- Reactive melt percolation produced spatially heterogeneous changes in the composition and texture of the mantle lithosphere atop the plume

- Refertilization, iron enrichment, and moderate heating of the base of the lithosphere may have locally lowered seismic velocities

- Strong axial-[100] to orthorhombic olivine CPO and "normal" oceanic lithosphere seismic anisotropy are preserved

Supporting Information:

- Supporting Information S1

- Data Set S1

- Data Set S2

- Data Set S3

- Data Set S4

- Data Set S5

Correspondence to:

A. Tommasi,

andrea.tommasi@umontpellier.fr

Citation:

Tommasi, A., Mameri, L., \& Godard, M. (2020). Textural and compositional changes in the lithospheric mantle atop the Hawaiian plume: Consequences for seismic properties. Geochemistry, Geophysics, Geosystems, 21, e2020GC009138. https://doi.org/ 10.1029/2020GC009138

\section{Textural and Compositional Changes in the Lithospheric Mantle Atop the Hawaiian Plume: Consequences for Seismic Properties}

\author{
Andréa Tommasi $^{1}$ (D), Lucan Mameri ${ }^{1}$ (D), and Marguerite Godard ${ }^{1}$ \\ ${ }^{1}$ Géosciences Montpellier, CNRS and Université de Montpellier, Montpellier, France
}

\begin{abstract}
We characterized the texture, composition, and seismic properties of the lithospheric mantle atop the Hawaiian plume by petrostructural analysis of 48 spinel peridotite xenoliths from four localities in three Hawaiian islands. Coarse-porphyroclastic peridotites with variable degrees of recrystallization, recorded by growth of strain-free neoblasts onto the deformed microstructure, predominate. Full evolution of this process produced equigranular microstructures. Some peridotites have coarse-granular microstructures. Coarse-granular and coarse-porphyroclastic peridotites have strong orthorhombic or axial-[100] olivine crystal-preferred orientations (CPOs). Recrystallization produced some dispersion and, locally, changed the olivine CPO towards axial-[010]. Enrichment in pyroxenes relative to model melting trends and pyroxenes with interstitial shapes and CPO uncorrelated with the olivine CPO imply refertilization by reactive melt percolation. The unusual spatial distribution of the recrystallized fraction, Ti enrichment, and Rare Earth Element fractionation in recrystallized, equigranular, and coarse-granular peridotites support that these microstructures are produced by static recrystallization triggered by melt percolation. However, there is no simple relation between microstructure and chemical or modal composition. This, together with marked variations in mineral chemistry among samples, implies multiple spatially heterogeneous melt-rock reaction events. We interpret the coarse-porphyroclastic microstructures and $\mathrm{CPO}$ as representative of the original oceanic lithosphere fabric. Annealing changed the microstructure to coarse-granular, but did not modify significantly the olivine CPO. Recrystallization produced moderate dispersion of the CPO. "Normal" oceanic lithosphere seismic anisotropy patterns are therefore preserved. Yet Fe enrichment, refertilization, and limited heating of the base of the lithosphere may reduce seismic velocities by up to $2 \%$, partially explaining negative velocity anomalies imaged at lithospheric depths beneath Hawaii.
\end{abstract}

\section{Introduction}

Hawaii is the archetype of a mantle plume. It displays voluminous intraplate volcanism with a clear age progression and well-developed bathymetric swell (Morgan, 1971). Body wave tomography models reveal a pancake-shaped low-velocity zone in the upper mantle beneath Hawaii, which continues with a more cylindrical shape into the transition zone and lower mantle (Wolfe et al., 2009, 2011). Rayleigh wave tomography images a broad low-velocity anomaly surrounded by high velocities in the upper mantle beneath the Hawaiian swell (Laske et al., 2011). Recent multiphase tomography models constrain this low-velocity anomaly to be composed of a pancake-shaped anomaly extending from the lithosphere-asthenosphere boundary (LAB) to $\sim 150-\mathrm{km}$ depth and a series of discontinuous anomalies, which are stronger SE of Hawaii, at $~ 250$ - to 400-km depth (Cheng et al., 2015). Sp receiver function studies imaged reflectors, which were interpreted as the LAB, at 75- to 95-km depth beneath Hawaii (Li et al., 2004; Rychert et al., 2013). Both receiver function and admittance data point to shallowing of the LAB along the island chain towards Kauai (Cadio et al., 2012; Li et al., 2004).

These geophysical observations are consistent with the predictions of numerical models exploring the interaction of a plume with a fast moving plate (Agrusta et al., 2013, 2015; Ballmer et al., 2011, 2013; Moore et al., 1998; Ribe \& Christensen, 1994). These models show that the plume spreads at the base of the lithosphere, producing limited thinning $(\leq 20 \mathrm{~km})$ in response to active small-scale convection within the plume-fed asthenosphere. They also predict multiple partial melting events: major melting at the plume impact point, which can explain the main island-forming volcanism, and minor melting downstream of the impact 


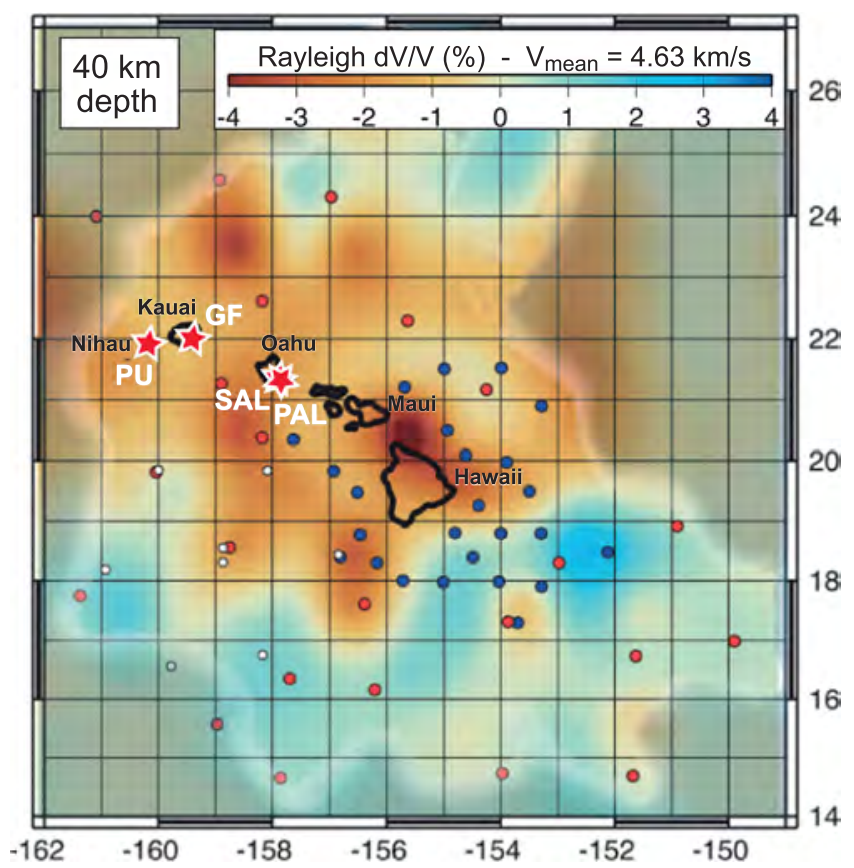

Figure 1. Provenance of the studied mantle xenoliths (stars): Salt Lake (SAL) and Pali (PAL) in Oahu, Grove Farm (GF) in Kauai, and Pu'uwai (PU) in Nihau, relative to a Rayleigh velocity model at 40-km depth (Laske et al., 2011). Dots mark the location of seismic stations of the Hawaiian PLUME experiment used in the inversion; colors indicate stations deployed at different phases of the PLUME experiment. point, in response to small-scale convection, which may account for the late, rejuvenated-stage volcanism. Yet, the effect of the plume activity on the lithospheric mantle remains poorly characterized.

Surface wave and multiphase tomography models portray reduced seismic velocities (by up to $-3 \%$ ) in the lithospheric mantle within $150 \mathrm{~km}$ from the volcanic chain (Figure 1) (Cheng et al., 2015; Laske et al., 2011). However, the weak heat flow anomaly in the swell implies modest heating $\left(100-200^{\circ} \mathrm{C}\right)$ confined to the base of the lithosphere (Von Herzen et al., 1989). Active-source surveys on the northeastern Hawaiian Arch image high $P$ wave velocities (up to $8.65 \mathrm{~km}$ / s) and strong azimuthal $P$ wave anisotropy (9\%) at sub-Moho depths (Morris et al., 1969a; Ohira et al., 2018), typical of an undisturbed old oceanic plate. However, Ohira et al. (2018) also imaged multiple, laterally discontinuous mantle reflectors at depths of 30-85 km below the seafloor, which they interpreted as produced by frozen melt layers or lenses. Could the seismic anomalies in the deep lithosphere have partly a compositional origin?

Petrological and geochemical studies of peridotite and pyroxenite xenoliths exhumed by the rejuvenated-stage volcanism in Oahu concluded that the peridotites represent a residual oceanic mantle lithosphere metasomatically modified by interaction with plume-related melts and fluids and the pyroxenites, the product of partial crystallization of these melts in the mantle lithosphere at 50 to 70-km depth (Ducea et al., 2002; Goto \& Yokoyama, 1988; Keshav et al., 2007; Sen, 1988; Sen et al., 1993). Trace element and isotopic signatures point to a spatially heterogeneous metasomatism involving melts with variable compositions (Bizimis et al., 2003, 2007; Ducea et al., 2002; Sen, 1988; Sen et al., 1993, 2005). Analysis of the equilibrium temperatures and pressures of the pyroxenites implies warming of the base of the lithospheric mantle by the percolating magmas (Keshav et al., 2007; Sen, 1988; Sen et al., 2005). It is not clear, however, whether this warming corresponds to a large-scale heating of the base of the lithosphere in response to the plume activity or if it is controlled by melt transport and crystallization and, therefore, local and transient.

Microstructures of the Hawaiian peridotite xenoliths are varied. Mercier and Nicolas (1975) classified them into protogranular, porphyroclastic, and equigranular and interpreted the variation in microstructure from protogranular to porphyroclastic and then to equigranular as recording increasing finite strain. In contrast, Goto and Yokoyama (1988), based on the observation that peridotites with fine-grained equigranular microstructures were on average more $\mathrm{Fe}$ and $\mathrm{Na}$ rich than coarse-grained ones, proposed that the recrystallization leading to the development of the equigranular microstructures was related to metasomatism.

To explore the effects of the plume activity on the mantle lithosphere atop Hawaii, we analyzed the microstructures, crystal-preferred orientations (CPOs), and mineral compositions and calculated equilibrium temperatures and seismic properties of 48 spinel peridotites and three garnet-spinel pyroxenites from four localities in three Hawaiian islands: Salt Lake (SAL, 19 xenoliths) and Pali (PAL, 18 xenoliths) in Oahu, Grove Farm (GF, 11 xenoliths) in Kauai, and Pu'uwai (PU, 3 xenoliths) in Nihau (Figure 1). All xenoliths were exhumed by the small-volume rejuvenated-stage alkalic volcanism, which postdates the main, shield volcano formation episodes by 0.6 to 4 Ma (Cousens \& Clague, 2015; Jackson \& Wright, 1970).

\section{Methods}

\subsection{Mineral Chemistry Analysis and Geothermometry}

Major element composition of olivine, orthopyroxene, clinopyroxene, and spinel, as well as garnet in the garnet-spinel pyroxenites, were analyzed in 39 samples representative of the different microstructural groups and modal composition range using a Cameca SX100 electron microprobe analyser (EPMA) at the 
University of Montpellier. Number of analyzed grains, average compositions, standard deviations, information on core-rim variations for each sample and analytical conditions are presented in the Supporting Information, Table S1.

Trace element compositions of orthopyroxene, clinopyroxene, and garnet in 18 samples from Salt Lake and Pali were measured at the University of Montpellier using a 1991 vintage VG Plasmaquad II turbo ICP-MS, coupled with a Geolas (Microlas) automated platform housing a 193-nm Compex 102 laser from LambdaPhysik following the method described in Drouin et al. (2009). Analyses were performed on $\sim 150 \mu \mathrm{m}$ thick sections, cleaned with alcohol to remove carbon coating after EPMA analyses, and dried under nitrogen. Signals were acquired in time-resolved acquisition, devoting 2 min for the blank and $1 \mathrm{~min}$ for measurement of the analytes. The laser was fired using an energy density of $15 \mathrm{~J} / \mathrm{cm}^{2}$ at a frequency of $5 \mathrm{~Hz}$ using a spot size of $102 \mu \mathrm{m}$. This resulted in a sensitivity of $\sim 4,000 \mathrm{cps} / \mathrm{ppm}$ for In based on measurements on the NIST 612 certified reference material. Oxide level, measured using the ThO/Th ratio, was below 0.7\%. Data were reduced using the GLITTER software (Van Achterberg et al., 2001) using a linear fit to ratio. ${ }^{43} \mathrm{Ca}$ was used as an internal standard and analyte concentrations were calibrated against the NIST 612 rhyolitic glass using the values given in Pearce et al. (1997). This resulted in a 5\% to 11\% precision (1 sigma) evaluated by repeated analyses of reference basalt BR (Table S2).

When both orthopyroxene and clinopyroxene were present, equilibrium temperatures were calculated using the two-pyroxene Fe-Mg exchange geothermometer from Brey and Koehler (1990) for both cores and rims. When possible, orthopyroxene-clinopyroxene pairs in contact were used, but textural equilibrium cannot be ensured for all samples. Equilibrium temperatures were also estimated using the $\mathrm{Ca}$ and $\mathrm{Al}$ in orthopyroxene geothermometers from Brey and Koehler (1990) and Witt-Eickschen and Seck (1991). When exsolutions were present, calculations were performed using the exsolved compositions; the calculated temperatures record therefore the last equilibrium achieved by the samples before extraction from the mantle. Equilibrium pressures were estimated for two garnet-spinel pyroxenites from Salt Lake using the orthopyroxene-garnet barometer of Nickel and Green (1985).

\subsection{EBSD Data Acquisition and Treatment}

CPOs of olivine, pyroxenes, garnet, and spinel were measured at the SEM-EBSD facility at Geosciences Montpellier by indexing of electron backscatter diffraction (EBSD) patterns produced by interaction of an incident electron beam with a carefully polished thin section tilted at $20^{\circ}$ to the electron beam. Measurements were performed in a JEOL JSM 5600 scanning electron microscope using an acceleration voltage of $17 \mathrm{kV}$ and a working distance of $23 \mathrm{~mm}$. Maps covering almost entirely each thin section were obtained using steps between 15 and $35 \mu \mathrm{m}$, depending on grain size. Indexing rates ranged between 80\% and $90 \%$. Lower indexation rates (70-80\%) were obtained for a few peridotites (GF1B2F, GF4) that show some alteration along grain boundaries due to reaction with the host basalt. Orthopyroxene was seldom misindexed as clinopyroxene. Inaccurate mineral determination and misindexing due to olivine pseudo-symmetry were corrected by careful post-acquisition data treatment controlled by comparing EBSD maps and optical microscopy observations.

Modal compositions were approached as the area fraction occupied by each mineral on the EBSD maps, recalculated for a 100\% indexation. This method might slightly underestimate the orthopyroxene modal content (by $<5 \%$ ), since this phase tends to have more indexation errors than olivine or clinopyroxene.

CPO data are displayed in pole figures, presented as lower hemisphere stereographic projections. Data are presented as one measurement per pixel; this accounts for the area occupied by each orientation, giving more weight to coarse crystals. When the foliation and lineation could be identified, the orientation of the main crystallographic directions-[100], [010], and [001] for olivine and pyroxenes - is plotted relative to the principal axes of the strain ellipsoid X, Y, and Z. In some samples, the orientation of the foliation and lineation could not be defined. To facilitate comparison between different samples, we present the CPO data of all samples rotated into a common orientation, in which the maximum concentration of olivine [100] and [010] axes are parallel to the E-W and the N-S directions of the pole figure, respectively. This reorientation is justified a posteriori by the analysis of the olivine CPO, which is characterized by clear maxima of [100] and [010], consistent with deformation by dislocation creep with dominant activation of the [100](010) slip system in all samples. 
Table 1

Microstructures, Modal Compositions, Bulk Rock Mg\# and Cr\#, Equilibrium Temperatures and Pressures

\begin{tabular}{|c|c|c|c|c|c|c|c|c|c|c|c|c|c|c|c|}
\hline \multirow[b]{3}{*}{ Sample } & \multirow[b]{3}{*}{ Microstructure } & \multirow{3}{*}{$\begin{array}{l}\text { Ol Rex } \\
\text { fraction } \\
(\%)\end{array}$} & \multirow[b]{3}{*}{$\mathrm{Ol}$} & \multirow[b]{3}{*}{ Opx } & \multirow[b]{3}{*}{ Cpx } & \multirow[b]{3}{*}{$\mathrm{Sp}$} & \multirow[b]{3}{*}{ Mg\# } & \multirow[b]{3}{*}{$\mathrm{Cr} \#$} & \multicolumn{6}{|c|}{ Equilibrium temperatures $\left({ }^{\circ} \mathrm{C}\right)$} & \multirow{3}{*}{$\begin{array}{l}\text { Pressure } \\
(\mathrm{GPa})^{\mathrm{c}}\end{array}$} \\
\hline & & & & & & & & & \multicolumn{2}{|c|}{ Two-pyroxene ${ }^{\mathrm{a}}$} & \multicolumn{2}{|c|}{ Ca-in-Opx ${ }^{a}$} & \multicolumn{2}{|c|}{ Al-in-Opx ${ }^{b}$} & \\
\hline & & & & & & & & & Core & Rim & Core & Rim & Core & Rim & \\
\hline SAL10 & $\mathrm{CP}$ & 10 & 86 & 10 & 3 & 1 & 85.8 & 22.3 & 1010 & 1009 & 985 & 991 & 1023 & 1074 & \\
\hline SAL36b & $\mathrm{CP}$ & $15^{\mathrm{d}}$ & 73 & 23 & 4 & 0 & & & & & & & & & \\
\hline PAL1 & $\mathrm{CP}$ & $20^{\mathrm{d}}$ & 69 & 29 & 2 & 0 & 89.0 & 11.4 & 908 & 923 & & 1029 & & 914 & \\
\hline PAL2 & $\mathrm{CP}$ & $15^{\mathrm{d}}$ & 69 & 18 & 13 & 1 & & & & & & & & & \\
\hline PAL10 & $\mathrm{CP}$ & 5 & 69 & 20 & 10 & 1 & 90.0 & 9.7 & 866 & 867 & 894 & 910 & 920 & 952 & \\
\hline PAL18 & $\mathrm{CP}$ & 4 & 65 & 22 & 13 & 1 & 89.9 & 7.9 & 874 & 989 & 902 & 903 & 960 & 1004 & \\
\hline PAL23a & $\mathrm{CP}$ & $15^{\mathrm{d}}$ & 70 & 21 & 8 & 1 & 89.7 & 9.9 & 881 & 868 & 912 & 964 & 954 & 957 & \\
\hline PAL25a & $\mathrm{CP}$ & 10 & 63 & 24 & 12 & 1 & & & & & & & & & \\
\hline PU1B1 & $\mathrm{CP}$ & 4 & 68 & 22 & 10 & 0 & & & & & & & & & \\
\hline 70SAL11 & CG & 43 & 67 & 28 & 4 & 1 & 90.6 & 13.5 & 920 & 932 & & 947 & & 1008 & \\
\hline SAL6-25 & CG & 46 & 79 & 15 & 5 & 1 & 91.4 & 18.4 & 965 & 965 & & 950 & & 1043 & \\
\hline SAL35 & CG & 46 & 61 & 33 & 5 & 1 & 85.0 & 7.3 & 950 & 977 & 981 & 992 & 996 & 998 & \\
\hline SAL38 & CG & 56 & 56 & 36 & 8 & 0 & 88.1 & 7.8 & 931 & 933 & 954 & 937 & 1000 & 1038 & \\
\hline PAL26 & CG & 25 & 44 & 48 & 7 & 1 & & & & & & & & & \\
\hline GF1B1 & CG & 42 & 77 & 21 & 2 & 0 & & & & & & & & & \\
\hline GF13d-Du & CG & 34 & 98 & 0 & 1 & 0 & 87.2 & 43.7 & & & & & & & \\
\hline GF13c & Rex & 11 & 71 & 25 & 4 & 0 & 89.8 & 10.6 & 776 & 748 & & 866 & & 896 & \\
\hline PAL14a & Rex & 13 & 63 & 21 & 15 & 1 & & & & & & & & & \\
\hline GF12 & Rex & 15 & 85 & 14 & 1 & 0 & 90.6 & 20.5 & 845 & 900 & & 890 & & 896 & \\
\hline SAL16 & Rex & 15 & 73 & 15 & 12 & 0 & 89.9 & 10.7 & 1008 & 1012 & 971 & 1026 & 1040 & 1093 & \\
\hline PAL25b & Rex & 18 & 55 & 29 & 14 & 3 & 89.0 & 7.4 & 911 & 909 & 934 & 921 & 897 & 899 & \\
\hline PAL21 & Rex & 20 & 71 & 17 & 10 & 2 & & & & & & & & & \\
\hline PAL3 & Rex & 21 & 50 & 30 & 16 & 4 & 88.4 & 6.3 & 890 & 886 & 906 & 944 & 984 & 913 & \\
\hline PAL20 & $\operatorname{Rex}$ & 21 & 62 & 20 & 17 & 1 & & & & & & & & & \\
\hline PAL24 & $\operatorname{Rex}$ & 21 & 52 & 33 & 13 & 2 & 88.7 & 7.2 & 958 & 945 & 953 & 935 & 921 & 945 & \\
\hline SAL3 & $\operatorname{Rex}$ & 22 & 73 & 13 & 12 & 1 & 88.7 & 12.7 & 923 & 969 & 940 & 952 & 1007 & 1015 & \\
\hline SAL20 & Rex & 22 & 73 & 21 & 6 & 0 & 90.4 & 10.4 & 932 & 947 & & 979 & & 1005 & \\
\hline GF2a & Rex & 23 & 81 & 17 & 2 & 0 & 90.5 & 26.5 & 975 & 922 & & 1019 & & 958 & \\
\hline SAL2 & $\operatorname{Rex}$ & 24 & 66 & 20 & 12 & 1 & 89.8 & 13.4 & 942 & 952 & 930 & 940 & 1028 & 1025 & \\
\hline PALD4 & Rex & 25 & 44 & 35 & 20 & 1 & 88.8 & 5.1 & 895 & 835 & & 909 & & 902 & \\
\hline PAL15 & Rex & 27 & 89 & 2 & 8 & 1 & 89.2 & 19.4 & 935 & 886 & & 967 & & 962 & \\
\hline PU4A & Rex & 28 & 79 & 19 & 2 & 0 & 89.2 & 17.5 & 876 & 837 & & 917 & & 932 & \\
\hline SAL6-58 & Rex & 32 & 60 & 20 & 18 & 1 & 89.4 & 7.4 & 924 & 921 & 937 & 965 & 981 & 987 & \\
\hline GF1B2 & Rex & 33 & 75 & 20 & 3 & 2 & & & & & & & & & \\
\hline PU5-6 & Rex & 33 & 85 & 11 & 2 & 1 & 88.2 & 30.8 & 830 & 880 & & 909 & & 896 & \\
\hline SAL18 & $\operatorname{Rex}$ & 34 & 78 & 16 & 6 & 0 & 89.0 & 11.6 & 917 & 966 & & 923 & & 1029 & \\
\hline SAL126-6 & $\operatorname{Rex}$ & 38 & 72 & 20 & 7 & 0 & & & & & & & & & \\
\hline GF4 & Rex & 39 & 58 & 26 & 14 & 2 & 89.7 & 12.3 & 763 & 752 & & 877 & & 944 & \\
\hline GF13d-Hz & Rex & 40 & 82 & 14 & 4 & 0 & 87.4 & 17.1 & & 918 & & 976 & & 961 & \\
\hline PAL7 & Rex & 42 & 68 & 20 & 13 & 0 & 89.4 & 6.0 & 851 & 864 & 898 & 917 & 928 & 945 & \\
\hline GF8 & EQ & 50 & 64 & 26 & 9 & 1 & 89.5 & 9.3 & 787 & 755 & & 863 & & 924 & \\
\hline PAL12 & EQ & 50 & 72 & 23 & 4 & 0 & 88.4 & 10.2 & 953 & 944 & 1001 & 991 & 942 & 980 & \\
\hline GF9 & EQ & 53 & 74 & 14 & 10 & 2 & 89.4 & 12.7 & & & & 919 & & 960 & \\
\hline GF5 & EQ & 56 & 80 & 20 & 0 & 0 & 90.7 & 15.8 & 810 & 814 & & 856 & & 939 & \\
\hline 69SAL63a & EQ & 58 & 74 & 19 & 7 & 0 & 89.8 & 12.6 & 934 & 864 & & 985 & & 1056 & \\
\hline 69SAL41a & EQ & 59 & 69 & 20 & 9 & 2 & 89.5 & 9.0 & 933 & 943 & & 958 & & 999 & \\
\hline SAL37b & EQ & 71 & 57 & 35 & 8 & 0 & & & & & & & & & \\
\hline PAL8 & EQ & 76 & 99 & 1 & 0 & 0 & 88.4 & 28.1 & & & & & & & \\
\hline SAL33 & Mag & $5^{\mathrm{e}}$ & 30 & 25 & 38 & 2 & 82.2 & & 998 & 1011 & 1017 & 1022 & 945 & 954 & 1.45 \\
\hline SAL14 & Mag & $9^{\mathrm{e}}$ & 1 & 2 & 86 & 3 & 74.7 & & 937 & & 993 & & & & 1.25 \\
\hline SAL7 & Mag & $8^{\mathrm{e}}$ & 2 & 0 & 88 & 2 & 75.8 & & & & & & & & \\
\hline
\end{tabular}

Note. Mg\# and C\# estimated from average chemical composition and modal contents (area \%) of each mineral.

Abbreviations: CG, coarse-granular; EQ, equigranular; Mag, magmatic; Rex, recrystallized.

${ }^{a}$ Two-pyroxene thermometer and Ca-in-opx thermometer (Brey \& Koehler, 1990). ${ }^{b}$ Al-in-opx thermometer (Witt-Eickschen \& Seck, 1991). $\quad{ }^{c}$ Orthopyroxenegarnet barometer (Nickel \& Green, 1985). ${ }^{\mathrm{d}}$ High apparent recrystallized fraction because a few coarse olivine crystals have low GOS. ${ }^{\mathrm{e}} \mathrm{Garnet}$ modal fraction (\%); there is no recrystallized olivine in the pyroxenites 


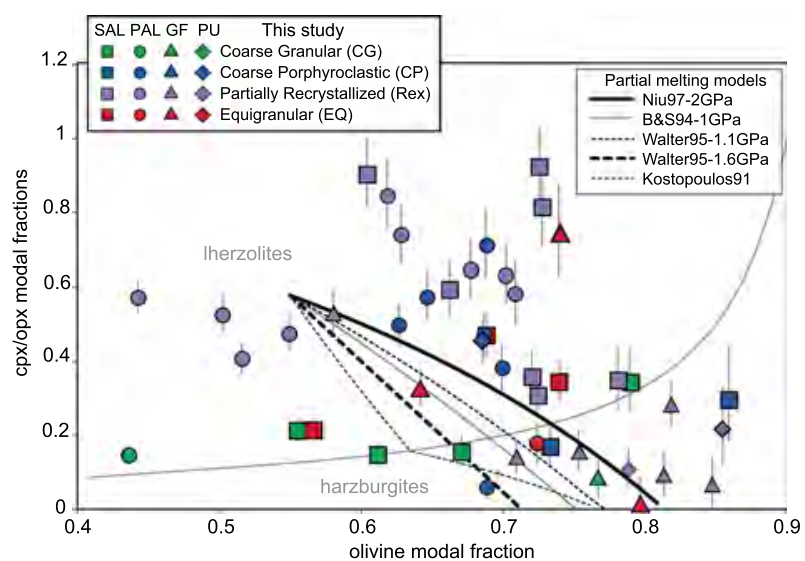

Figure 2. Modal composition as a function of the xenolith origin and microstructure plotted on a clinopyroxene/orthopyroxene versus olivine modal content diagram for comparison with evolutions predicted by isobaric melting models calculated for an initial modal composition of 55\% olivine, $28 \%$ opx, $15 \%$ $\mathrm{cpx}$, and $2 \%$ spinel. Error bars represent $\pm 1 \%$ uncertainty in the determination of the modal composition.
The strength (intensity) of the olivine CPO was quantified using the dimensionless $\mathrm{J}$ index, which is the volume-averaged integral of squared orientation densities. The J index was calculated using the MTEX toolbox in MATLAB (http://mtex.googlecode.com) (Bachmann et al., 2011; Hielscher and Schaeben, 2008) with orientation distribution functions (ODFs) calculated using a "de la Vallée Poussin" kernel with a half width of $10^{\circ}$. This calculation was performed using both one-orientation datum per pixel and the mean orientation of each grain. The first option, which is presented in the figures, allows relating the CPO strength to variations in grain size. Coarse crystals contribute more to the $\mathrm{J}$ index, as they do for the anisotropy of physical properties. In naturally deformed peridotites, the J index, when calculated using the same parameters as in this study, typically ranges between 1 (random CPO) and 18, with a median at 4.8 (Tommasi \& Vauchez, 2015).

The symmetry of the olivine CPO is characterized by the dimensionless BA index (Mainprice, Bachmann, et al., 2014). The BA index allows a classification of the olivine CPO symmetry into three types: axial-[010], characterized by a point concentration of [010] and a girdle distribution of [100] (BA index $<0.35$ ); orthorhombic, characterized by point concentrations of both [100] and [010] $(0.35<$ BA index $<0.65)$; and axial-[100], characterized by a point concentration of [100] and a girdle distribution of [010] (BA index > 0.65).

The automatic grain detection routine in the MTEX toolbox (Bachmann et al., 2011) is used for quantitative analysis of grain sizes and shapes. Grain boundaries are defined by misorientations between neighboring pixels $>15^{\circ}$. Intracrystalline orientation gradients, which are a proxy for the dislocation density, were quantified by the analysis of the misorientation of each pixel relative to the average orientation of the grain (M2M). The decrease in the mean M2M value (averaged over the entire sample) is used as a proxy for quantifying the degree of recrystallization of the sample. Both dynamic recrystallization and annealing (static recrystallization) result in decrease of the intracrystalline dislocation density due to recovery and growth of grains with low dislocation densities, such as newly crystallized or recrystallized grains. Recrystallized area fractions for olivine are estimated as the area fraction occupied by grains with a spread in orientation (GOS, which is the average $\mathrm{M} 2 \mathrm{M}$ in the grain) $<1.5^{\circ}$ relative to the total area occupied by olivine grains. The sinuosity of grain boundaries is characterized by the shape factor, which is the ratio between the perimeter of the grain and the perimeter of a circle with the same area. The shape factor decreases during annealing.

\subsection{Seismic Properties}

Seismic properties were calculated using the CPO of all major phases and their respective modal content estimated from EBSD maps (Mainprice, 1990; Mainprice, Hielscher, \& Schaeben, 2014). In situ seismic properties were estimated using elastic tensors and density of olivine and pyroxenes recalculated based on the geotherm constrained based on the xenoliths equilibrium data and experimentally determined pressure and temperature derivatives (Abramson et al., 1997; Chai et al., 1997a, 1997b; Collins \& Brown, 1998; Reichmann \& Jacobsen, 2004). Voigt-Reuss-Hill averaging was applied in all calculations.

Average seismic properties for the lithospheric mantle beneath Oahu and Kauai-Nihau were estimated by averaging the elastic constant tensors calculated using the CPO data of the different samples rotated into a common structural reference frame, which assumes a geographically coherent orientation of the foliation and lineation beneath the islands. These values represent therefore maximum estimates of the seismic anisotropy that may be produced by the studied xenolith suite. A similar averaging was also performed for each microstructural group to evaluate the effect of changes in the microstructure on seismic anisotropy. 

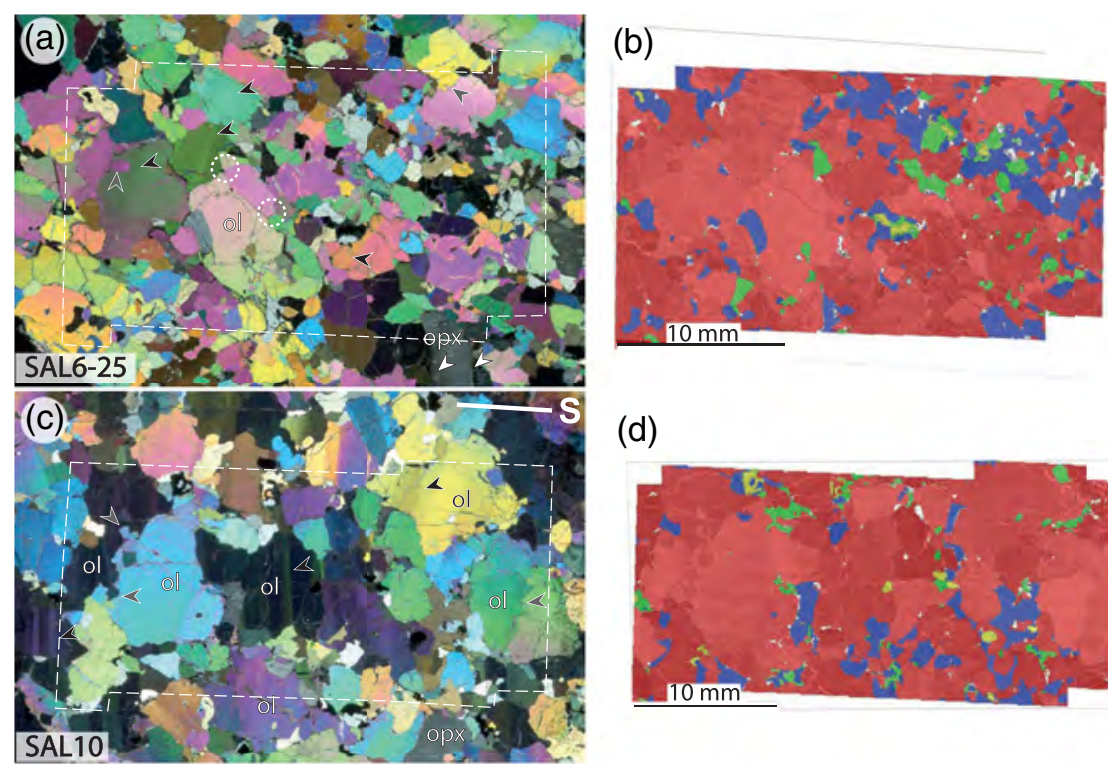

(d)
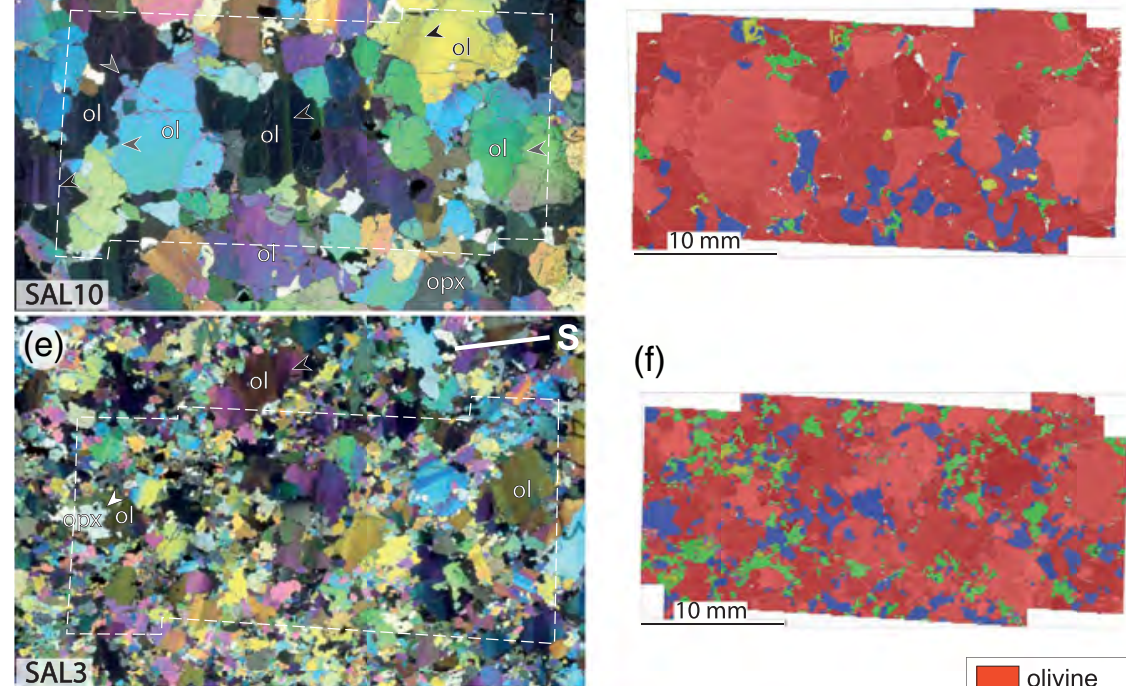

(f)
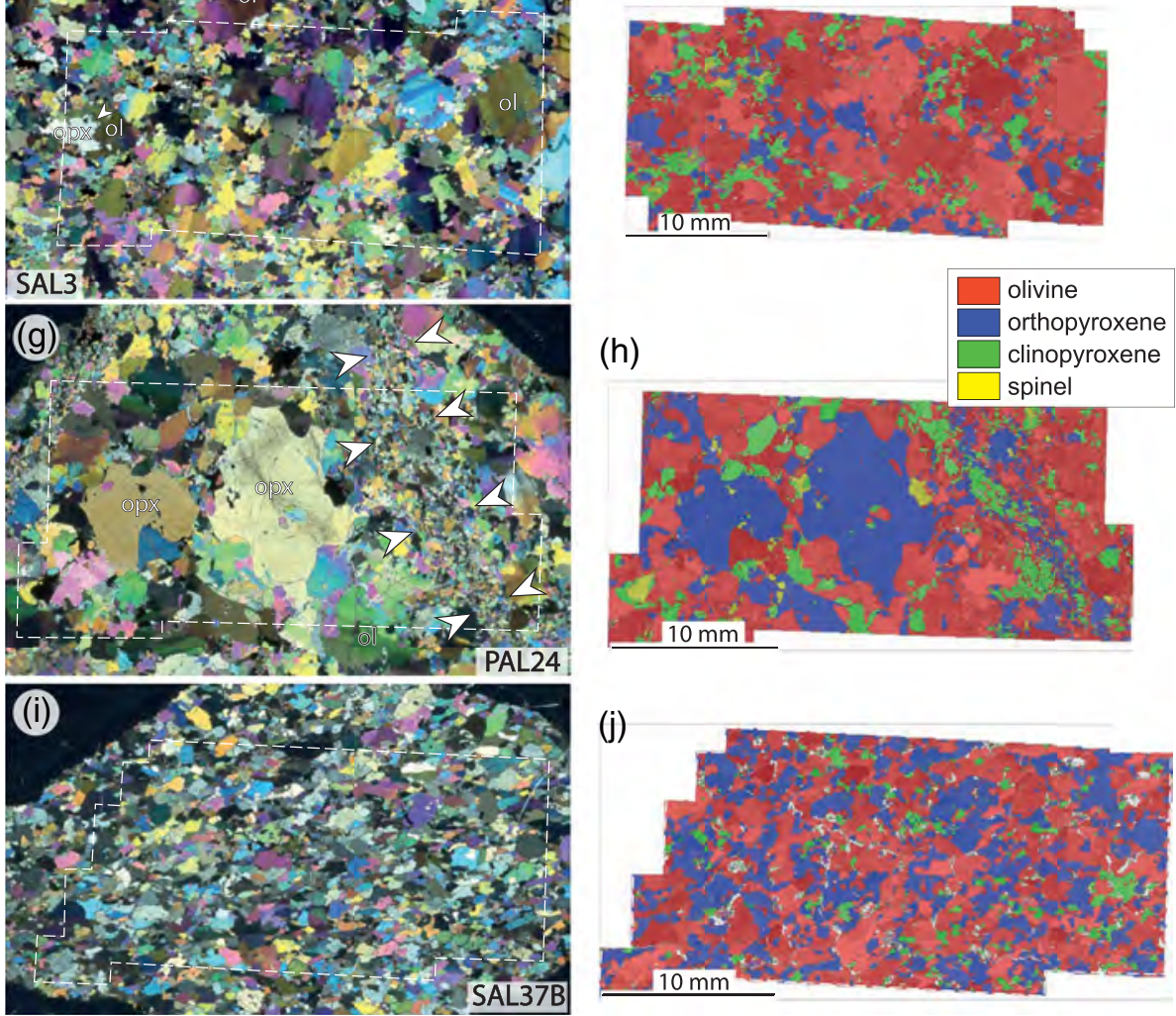

Figure 3. Photomicrographs in cross-polarized light (a, c, e, g, i) and EBSD phase maps (b, d, f, h, j) illustrating characteristic microstructures of Hawaii peridotite xenoliths: (a, b) coarse-granular, (c, d) coarse-porphyroclastic, (e, f) partially recrystallized coarse-porphyroclastic with dispersed distribution of the neoblasts, $(\mathrm{g}, \mathrm{h})$ partially recrystallized coarse-porphyroclastic with recrystallization and pyroxene enrichment concentrated in a vein-like domain (indicated by white arrows in $\mathrm{g}$ ), and (i, j) equigranular. $\mathrm{S}$ in (c, e) marks the trace of the foliation in the thin section plane. White dashed polygons in (a, c, e, g, i) delimit the area covered by the EBSD maps. 

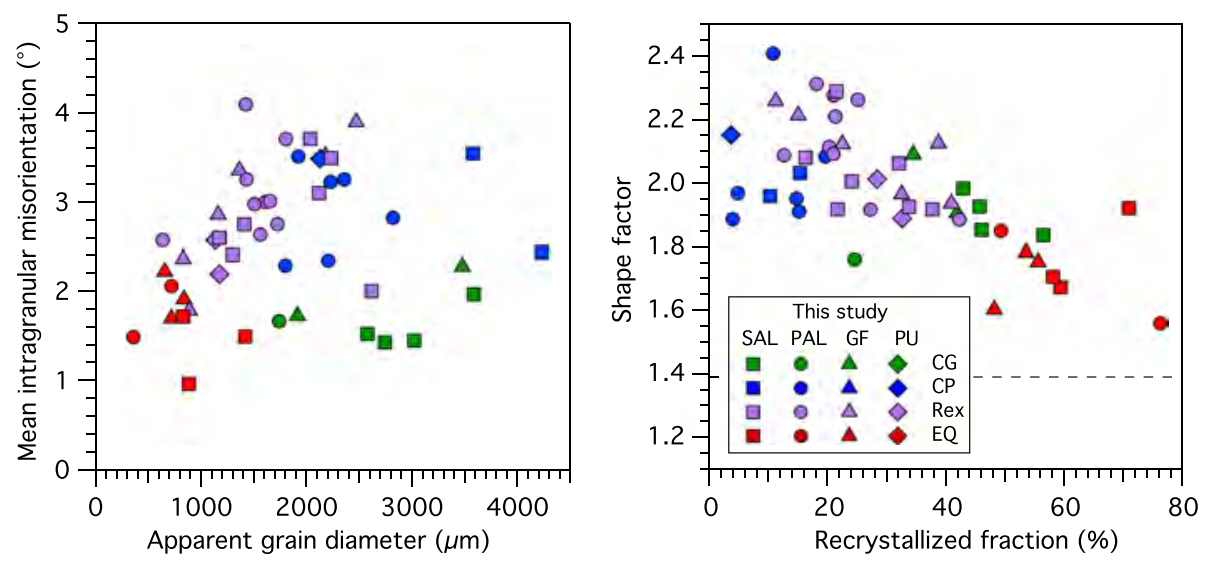

Figure 4. Quantitative microstructural parameters derived from EBSD maps. (a) 2D apparent olivine grain size (defined as the area-weighted average of the diameter of circles with the same area as the grains) as a function of the average mean intragranular misorientation (M2M) in olivine. Coarse-granular peridotites can be distinguished from coarse-porphyroclastic peridotites by the lower average intragranular misorientation in olivine, whereas partially recrystallized and equigranular peridotites are characterized by decrease in both grain size and intragranular misorientations. (b) Decrease in the sinuosity of grain boundaries with increasing recrystallization. The sinuosity of grain boundaries is quantified by the area-weighted average shape factor (ratio between the perimeter of the grain and the perimeter of a circle with the same area). The recrystallized fraction is quantified by the area fraction composed by grains with low intragranular misorientation (grain orientation spread, GOS $<1.5^{\circ}$ ). Dashed line in (b) indicates the shape factor of a well-equilibrated synthetic olivine aggregate composed by polygonal crystals (Demouchy et al., 2019). Data presented in Table 2. Similar data for orthopyroxene and clinopyroxene are presented in Table S3.

\section{Results}

\subsection{Modal Compositions}

Lherzolites predominate among Salt Lake (SAL) and Pali (PAL) peridotites (26/34), whereas harzburgites predominate among Grove Farm (GF) and Pu'uwaii (PU) peridotites (9/14, Table 1). Dunites and wehrlites are rare. Comparison of the peridotites modal compositions with those predicted by different melting models highlights that most studied xenoliths have compositions that depart from partial melting trends (Figure 2), implying changes in modal composition in response to reactions with melts. Most often, modal compositions are homogeneous at the sample scale, suggesting diffuse porous flow (Figures 3d, 3f, and 3j). However, pyroxene-rich layers with diffuse limits record melt focusing in a few samples (Figures $3 \mathrm{~b}$ and $3 \mathrm{~h}$ ).

\subsection{Microstructures}

The studied peridotites display coarse-granular (CG; Figure 3a), coarse-porphyroclastic (CP; Figure 3c), partially recrystallized coarse-porphyroclastic (Rex; Figures 3e and 3g), or equigranular (EQ; Figure 3i) microstructures. These microstructural types encompass a continuous variation in grain size, shape factor (sinuosity of grain boundaries), and degree of internal deformation of the olivine crystals (Figure 4). There is no relation between modal composition and microstructure. Most studied Hawaii peridotites display partially recrystallized coarse-porphyroclastic microstructures (24/48), but this class encompasses a large variation in the degree of recrystallization (10-45\%, Table 1). The other microstructures are roughly equally represented (9/48 coarse-porphyroclastic, 7/48 coarse-granular, 8/48 equigranular). Except for Pu'uwai, where the three studied samples display coarse-porphyroclastic microstructures with variable degrees of recrystallization, all microstructural types are observed in every studied locality. The pyroxenites have coarse- or medium-grained magmatic cummulatic microstructures.

Coarse-granular peridotites have plurimillimetric olivine and orthopyroxene crystals (Figures $3 \mathrm{a}$ and $3 \mathrm{~b}$ ). Olivine 2D area-weighted mean diameters range between 1.7 and $3.6 \mathrm{~mm}$ (Figure 4). These peridotites do not display any shape-preferred orientation, except for GF1B1, which has a weak foliation marked by rare elongated orthopyroxene crystals (Figure 5a). Olivine crystals tend to display low intragranular misorientations (Figures 3a, 4, and 5a), but widely spaced subgrain boundaries are preserved in some crystals (black arrows in Figure 3a). The intensity of intragranular misorientation in olivine varies among the samples 

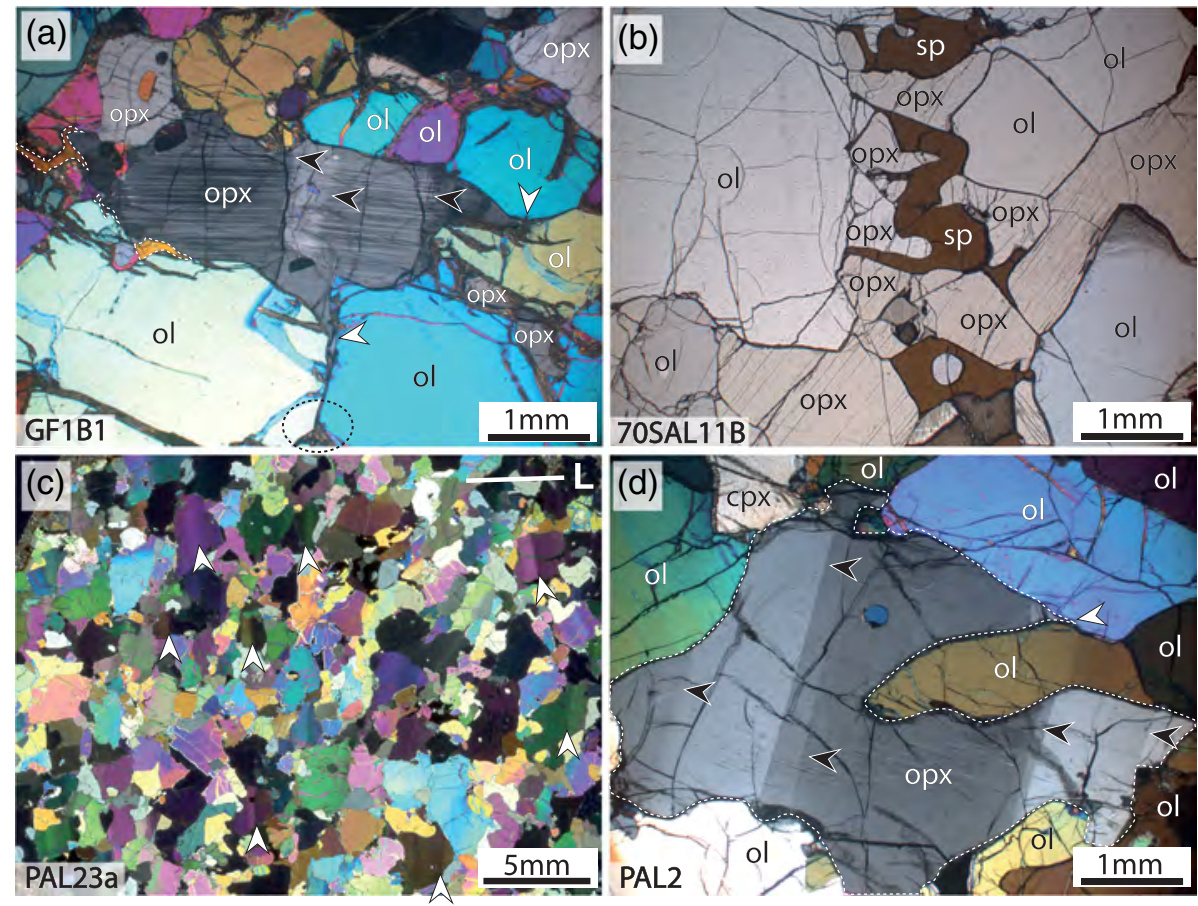

Figure 5. Photomicrographs in cross- or plane-polarized light showing characteristic features of $(a, b)$ coarse-granular and (c, d) coarse-porphyroclastic microstructures. (a) Olivine (ol) crystals with straight grain boundaries and no intragranular deformation coexisting with orthopyroxenes (opx) with kinks (black arrows) and clinopyroxene exsolutions, very irregular shapes and cusp-like terminations along olivine-olivine grain boundaries (white arrows). (b) Olivine and orthopyroxene crystals with polygonal shapes and interstitial-shape spinels within a pyroxene aggregate. (c) Coarse-grained olivine crystals with sinuous grain boundaries, undulose extinction, and well-developed subgrain boundaries with a preferred orientation at the sample scale (white arrows). (d) Orthopyroxene (opx) with irregular shape and cusp-like terminations along olivine-olivine grain boundaries (white arrow), kinks (black arrows), and clinopyroxene exsolutions. L in (c) marks the past flow direction defined by the olivine $\mathrm{CPO}$, which is at high angle to the apparent lineation defined by the olivine SPO.

(Figure 4, Table 2): it is lowest in SAL6-25 (average M2M of 1.4 ${ }^{\circ}$ ) and highest in GF1B1 (average M2M of $2.3^{\circ}$ ), which shows a microstructure transitional between coarse-granular and coarse-porphyroclastic. Olivine grain boundaries are sinuous or polygonal, forming locally triple junctions at $120^{\circ}$ (Figures 3a, 5a, and $5 b$ ). Orthopyroxene has very irregular grain shapes (Figure $3 b$ ) and sinuous boundaries, which often form cusp-like shapes when in contact with two olivines (white arrows in Figure 5a). Large orthopyroxene crystals show kink bands (black arrows in Figure 5a) and well-developed clinopyroxene exsolutions in the cores, but homogeneous cusp-like terminations (Figure 5a). Clinopyroxenes are usually smaller $(\leq 1 \mathrm{~mm})$ than orthopyroxenes and have interstitial-like shapes (Figure 3a). Spinels have irregular shapes and are usually associated with pyroxenes (Figure $5 b$ ).

Coarse-porphyroclastic peridotites have a continuous grain size variation with plurimillimetric olivine and orthopyroxene porphyroclasts (Figures $3 \mathrm{c}$ and $3 \mathrm{~d}$ ). Olivine $2 \mathrm{D}$ area-weighted mean diameters range between 1.8 and $4.2 \mathrm{~mm}$, with SAL samples presenting the coarser grain sizes (Figure 4). In contrast to coarse-granular peridotites, coarse-porphyroclastic peridotites display a weak, but clear shape-preferred orientation of olivine (Figure 3c). They also show a higher density of intracrystalline deformation features (Figures $3 \mathrm{c}$ and $5 \mathrm{c}$ ), quantified by higher average M2M values in olivine (2.4-3.6 $6^{\circ}$ Figure 4). Olivine-olivine grain boundaries are sinuous, denoting migration (Figures $3 \mathrm{c}$ and $5 \mathrm{c}$ ). Olivine crystals have undulose extinction and subgrain boundaries preferentially aligned normal to the crystals' elongation (Figure 3c). In rare samples, as in PAL23a, the olivine shape-preferred orientation has been modified by recrystallization, but the preferential alignment of subgrain boundaries in olivine still marks the normal to the lineation (Figure 5c). Orthopyroxene has very irregular shapes and does not show a shape-preferred orientation (Figure 3d). Most crystals have kinks and fine clinopyroxene exsolutions; some contain 
Table 2

Microstructural and CPO Parameters for Olivine Derived From EBSD

\begin{tabular}{|c|c|c|c|c|c|c|c|c|c|c|}
\hline Sample & Microstructure & $\begin{array}{l}\text { Olivine Rex } \\
\text { fraction (\%) }\end{array}$ & $\begin{array}{l}\mathrm{N}^{\circ} \text { of grains } \\
\text { analyzed }\end{array}$ & $\begin{array}{l}\mathrm{J} \text { index } \\
\text { (all) }\end{array}$ & $\begin{array}{c}\mathrm{J} \text { index } \\
(\operatorname{Rex})\end{array}$ & $\begin{array}{c}\text { BA } \\
\text { index }\end{array}$ & $\begin{array}{l}\mathrm{M} 2 \mathrm{M} \\
\left({ }^{\circ}\right)^{\mathrm{a}}\end{array}$ & $\begin{array}{l}\text { Grain size } \\
(\mu \mathrm{m})^{\mathrm{a}}\end{array}$ & $\begin{array}{l}\text { Shape } \\
\text { factor }^{\mathrm{a}}\end{array}$ & $\begin{array}{l}\text { Aspect } \\
\text { ratio }^{\mathrm{a}}\end{array}$ \\
\hline SAL10 & $\mathrm{CP}$ & 10 & 126 & 10.43 & 6.98 & 0.82 & 2.45 & 4235 & 1.96 & 1.53 \\
\hline SAL36b & $\mathrm{CP}$ & 15 & 166 & 8.98 & 4.37 & 0.81 & 3.55 & 3580 & 2.03 & 1.73 \\
\hline PAL1 & $\mathrm{CP}$ & 20 & 227 & 5.48 & 2.99 & 0.42 & 2.83 & 2826 & 2.09 & 1.68 \\
\hline PAL2 & $\mathrm{CP}$ & 15 & 395 & 4.81 & 3.12 & 0.60 & 2.36 & 2210 & 1.91 & 1.67 \\
\hline PAL10 & $\mathrm{CP}$ & 5 & 344 & 6.17 & 3.01 & 0.81 & 3.51 & 1930 & 1.97 & 1.75 \\
\hline PAL18 & $\mathrm{CP}$ & 4 & 183 & 6.44 & 5.28 & 0.59 & 3.26 & 2360 & 1.89 & 1.47 \\
\hline PAL23a & $\mathrm{CP}$ & 15 & 255 & 5.31 & 3.62 & 0.66 & 2.30 & 1806 & 1.95 & 1.97 \\
\hline PAL25a & $\mathrm{CP}$ & 11 & 487 & 5.38 & 1.86 & 0.56 & 3.23 & 2234 & 2.41 & 1.59 \\
\hline PU1B1 & $\mathrm{CP}$ & 4 & 287 & 5.78 & 2.41 & 0.60 & 3.49 & 2136 & 2.15 & 1.86 \\
\hline 70SAL11 & CG & 43 & 135 & 8.18 & 4.21 & 0.69 & 1.98 & 3588 & 1.99 & 1.65 \\
\hline SAL6-25 & CG & 46 & 207 & 6.63 & 4.24 & 0.72 & 1.44 & 2747 & 1.93 & 1.62 \\
\hline SAL35 & CG & 46 & 168 & 6.55 & 3.35 & 0.75 & 1.46 & 3022 & 1.86 & 1.51 \\
\hline SAL38 & CG & 56 & 138 & 6.37 & 3.84 & 0.66 & 1.54 & 2581 & 1.84 & 1.59 \\
\hline PAL26 & CG & 25 & 118 & 5.44 & 4.40 & 0.54 & 1.68 & 1744 & 1.77 & 1.86 \\
\hline GF1B1 & CG & 42 & 187 & 11.38 & 4.15 & 0.50 & 2.29 & 3480 & 1.90 & 1.55 \\
\hline $\begin{array}{l}\text { GF13d- } \\
\text { Du }\end{array}$ & CG & 34 & 265 & 6.80 & 4.24 & 0.42 & 1.74 & 1920 & 2.09 & 1.83 \\
\hline GF13c & Rex & 11 & 573 & 7.75 & 4.50 & 0.79 & 3.90 & 2477 & 2.26 & 1.68 \\
\hline PAL14a & Rex & 13 & 801 & 4.75 & 1.80 & 0.57 & 3.71 & 1807 & 2.09 & 1.64 \\
\hline GF12 & Rex & 15 & 788 & 8.94 & 5.31 & 0.85 & 3.52 & 2182 & 2.22 & 1.70 \\
\hline SAL16 & Rex & 15 & 333 & 4.24 & 2.80 & 0.71 & 3.11 & 2124 & 2.08 & 1.68 \\
\hline PAL25b & Rex & 18 & 1016 & 3.78 & 2.44 & 0.54 & 2.98 & 1510 & 2.31 & 1.80 \\
\hline PAL21 & Rex & 20 & 1675 & 3.82 & 2.35 & 0.72 & 3.26 & 1437 & 2.12 & 1.83 \\
\hline PAL3 & Rex & 21 & 809 & 3.48 & 2.43 & 0.76 & 3.00 & 1617 & 2.28 & 1.66 \\
\hline PAL20 & Rex & 21 & 352 & 6.22 & 2.96 & 0.71 & 2.64 & 1568 & 2.10 & 1.71 \\
\hline PAL24 & Rex & 21 & 1806 & 3.46 & 2.01 & 0.52 & 4.10 & 1428 & 2.21 & 1.61 \\
\hline SAL3 & Rex & 22 & 1155 & 5.15 & 2.96 & 0.70 & 3.71 & 2042 & 2.29 & 1.54 \\
\hline SAL20 & Rex & 22 & 333 & 4.30 & 2.70 & 0.82 & 3.50 & 2238 & 1.92 & 1.61 \\
\hline GF2a & Rex & 23 & 1038 & 9.49 & 8.99 & 0.39 & 3.36 & 1370 & 2.13 & 1.58 \\
\hline SAL2 & Rex & 24 & 1028 & 4.98 & 2.98 & 0.81 & 2.76 & 1416 & 2.00 & 1.94 \\
\hline PALD4 & Rex & 25 & 545 & 5.81 & 2.39 & 0.73 & 2.76 & 1730 & 2.26 & 1.63 \\
\hline PAL15 & Rex & 27 & 575 & 5.15 & 2.72 & 0.49 & 3.01 & 1658 & 1.92 & 1.58 \\
\hline PU4A & Rex & 28 & 1826 & 2.66 & 1.73 & 0.27 & 2.58 & 1143 & 2.01 & 1.66 \\
\hline SAL6-58 & Rex & 32 & 1173 & 3.48 & 2.57 & 0.74 & 2.61 & 1180 & 2.10 & 1.87 \\
\hline GF1B2 & Rex & 33 & 559 & 6.51 & 3.77 & 0.60 & 2.87 & 1168 & 1.70 & 1.97 \\
\hline PU5-6 & Rex & 33 & 889 & 2.92 & 2.26 & 0.45 & 2.21 & 1182 & 1.89 & 1.54 \\
\hline SAL18 & Rex & 34 & 272 & 5.84 & 3.07 & 0.43 & 2.02 & 2622 & 1.93 & 1.66 \\
\hline SAL126-6 & Rex & 38 & 918 & 4.46 & 2.50 & 0.67 & 2.42 & 1306 & 1.92 & 1.82 \\
\hline GF4 & Rex & 39 & 2003 & 3.03 & 2.61 & 0.13 & 2.37 & 838 & 2.13 & 1.62 \\
\hline $\begin{array}{c}\text { GF13d- } \\
\mathrm{Hz}\end{array}$ & Rex & 40 & 1216 & 2.72 & 2.08 & 0.38 & 1.80 & 898 & 1.94 & 1.88 \\
\hline PAL7 & Rex & 42 & 3543 & 1.94 & 1.80 & 0.77 & 2.58 & 645 & 1.89 & 1.75 \\
\hline GF8 & $\mathrm{EQ}$ & 50 & 3035 & 2.92 & 2.81 & 0.52 & 2.23 & 662 & 1.61 & 1.87 \\
\hline PAL12 & $\mathrm{EQ}$ & 50 & 3604 & 2.68 & 2.25 & 0.62 & 2.07 & 727 & 1.85 & 1.69 \\
\hline GF9 & $\mathrm{EQ}$ & 53 & 1905 & 2.35 & 2.25 & 0.51 & 1.71 & 728 & 1.78 & 1.75 \\
\hline GF5 & $\mathrm{EQ}$ & 56 & 1040 & 3.75 & 2.90 & 0.93 & 1.93 & 847 & 1.76 & 1.63 \\
\hline 69SAL63a & EQ & 58 & 424 & 4.39 & 2.80 & 0.66 & 1.51 & 1424 & 1.70 & 1.54 \\
\hline 69SAL41a & EQ & 59 & 932 & 3.01 & 2.65 & 0.69 & 1.73 & 837 & 1.67 & 1.71 \\
\hline SAL37b & $\mathrm{EQ}$ & 71 & 1594 & 2.36 & 1.95 & 0.77 & 0.97 & 890 & 1.92 & 1.87 \\
\hline PAL8 & EQ & 76 & 22078 & 1.87 & 1.42 & 0.31 & 1.50 & 369 & 1.56 & 1.50 \\
\hline
\end{tabular}

Abbreviations: CG, coarse-granular; CP, coarse-porphyroclastic; EQ, equigranular; Rex: recrystallized.

${ }^{a}$ Weighted (by the grain area) averages over the entire EBSD map. 2D measurements without any topological correction. Aspect ratios are minimum values since many thin sections are cut on random orientations and not on the XZ structural plane (normal to the foliation and parallel to the lineation).

rounded olivine inclusions (Figure 5d). Orthopyroxene grain boundaries are curved and, as in coarse-grained peridotites, tend to form cusp-like shapes at the contact with two olivine crystals (Figure 5d). Clinopyroxene has very irregular shapes and similar or smaller grain sizes than 


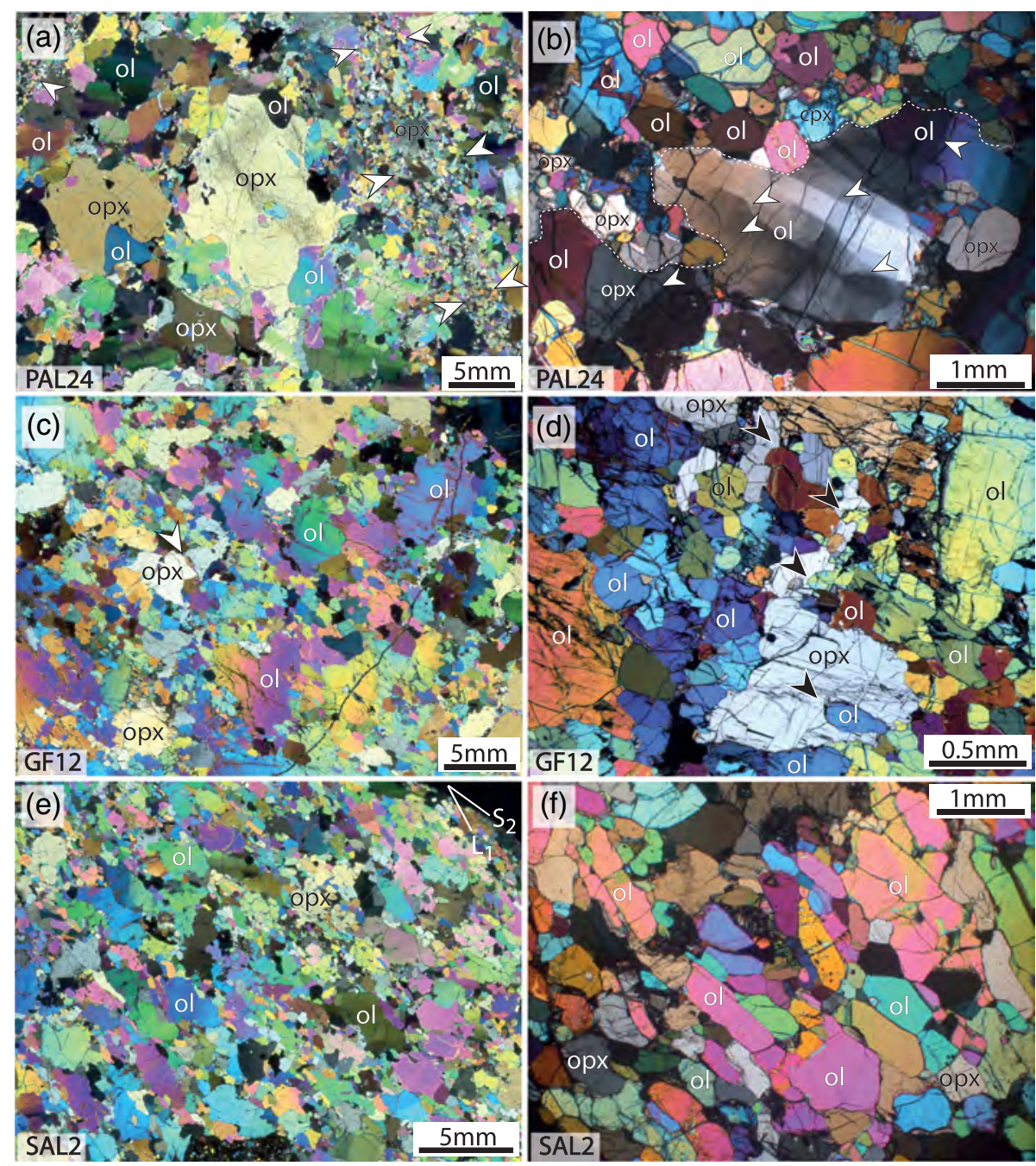

Figure 6. Photomicrographs in cross-polarized light displaying characteristic features of the partially recrystallized microstructure. (a) Recrystallization concentrated in a vein-like domain (delimited by the white arrows). (b) Irregular limit of the recrystallized domain (delimited by the white dashed line) showing polygonal strain-free neoblasts growing onto olivine (ol) porphyroclasts with well-developed subgrain boundaries (white arrows). (c, d) Diffusely distributed strain-free neoblasts with irregular shapes growing onto olivine porphyroclasts with undulose extinction coexisting with orthopyroxenes (opx) with very irregular shapes with embayments filled by olivine neoblasts (arrows in c and d). (e) Strongly recrystallized lherzolite showing elongated olivine porphyroclasts overgrown by heterogeneously distributed olivine neoblasts. (f) Detail of (e) illustrating the subhedral, tablet-like shapes of the olivine neoblasts and the interstitial shapes of orthopyroxene in recrystallized pockets. In (e), $\mathrm{L}_{1}$ is the elongation of olivine porphyroclasts and $\mathrm{S}_{2}$ is the shape-preferred orientation of neoblasts.

orthopyroxene (Figure 3d). It either forms aggregates with orthopyroxene \pm spinel or occurs as isolated, interstitial-like crystals (Figure 3d). Orthopyroxene exsolutions are common. Spinel occurs as irregularly shaped crystals within aggregates with pyroxenes or as inclusions in olivine.

Partially recrystallized coarse-porphyroclastic peridotites display variable degrees of recrystallization, recorded as finer-grained strain-free olivine neoblasts that overgrow the coarse-porphyroclastic microstructure (Figures 3e to 3h). Recrystallized fractions range from 10\% to 40\% (Figure 4). There are two modes of spatial distribution of the recrystallized fraction. In a few samples, as PAL14A, PAL24, and PALD4, recrystallization occurs essentially within planar, vein-like domains with diffuse limits, $1-8 \mathrm{~mm}$ wide, which crosscut the coarse-porphyroclastic microstructure (Figures 3g, 3h, 6a, and S1). These domains are enriched in pyroxenes relative to the remainder of the sample (Figure $3 \mathrm{~h}$ ). They are composed by fine-grained olivine 

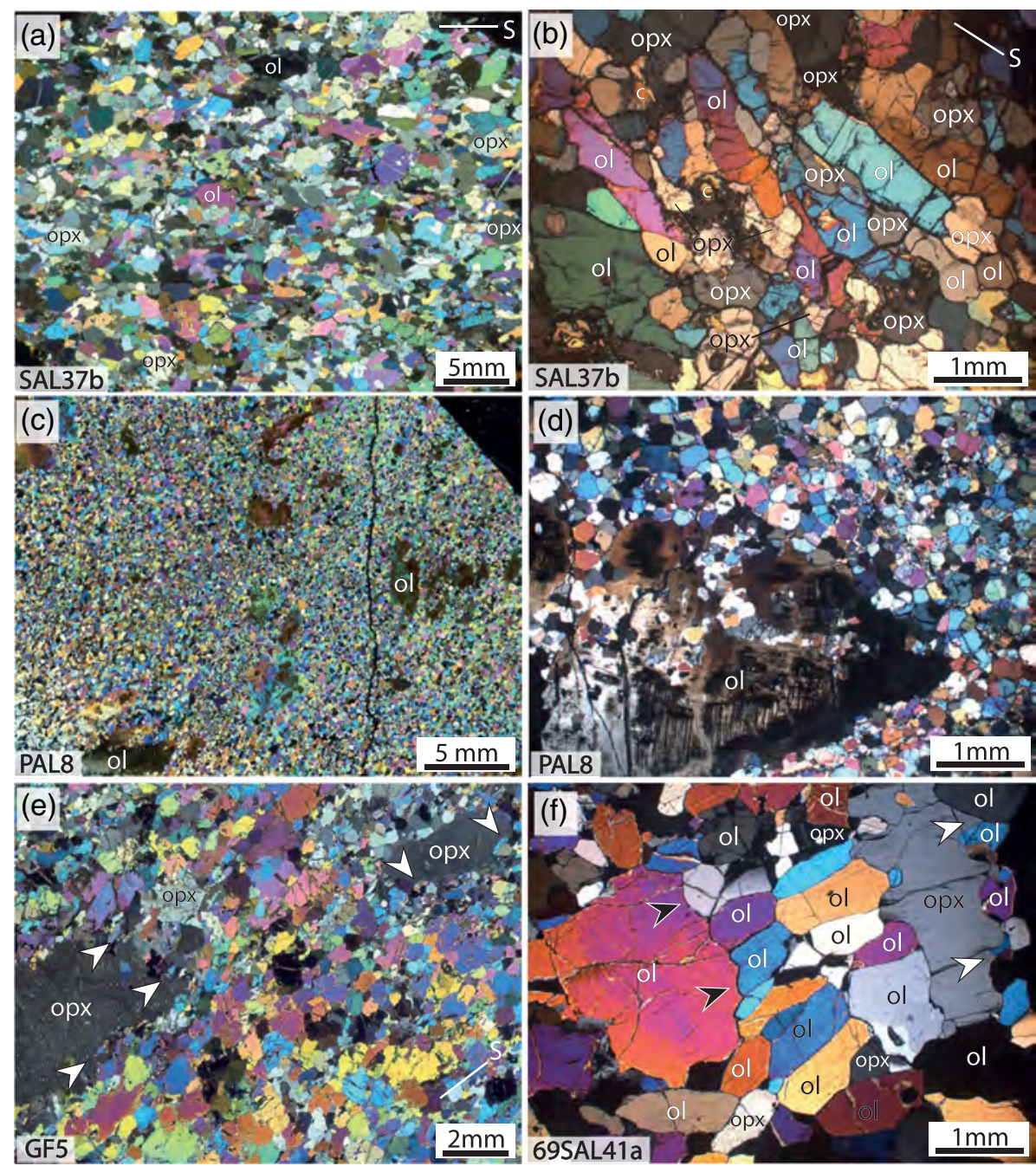

Figure 7. Photomicrographs in cross-polarized light displaying characteristic features of the equigranular microstructure. (a) Strongly recrystallized lherzolite with a weak foliation (S) marked by the shape-preferred orientation of the neoblasts. (b) Detail of (a) illustrating the coexistence of elongated olivine (ol) neoblasts with straight grain boundaries and small orthopyroxenes (opx) with interstitial shapes in the recrystallized domains. (c, d) Strongly recrystallized dunite with a few oxidized porphyroclasts enclosed in a matrix of non-oxidized polygonal neoblasts. (e) Strongly recrystallized harzburgite with coarse orthopyroxene crystals with very irregular shapes with embayments filled by olivine (white arrows). (f) Coexistence of relict olivine porphyroclasts with concave grain boundaries (black arrows), of olivine neoblasts with straight grain boundaries, and of orthopyroxenes with curved grain boundaries forming cusps at triple junctions with two olivine grains (white arrows). S, trace of foliation.

neoblasts (GOS $<1.5^{\circ}$ ) intermixed with orthopyroxene and clinopyroxene (Figure $6 \mathrm{~b}$ ). Both olivine and pyroxene neoblasts have irregular shapes, though olivine-olivine contacts tend to be straighter, and variable grain sizes. In the vicinity of the recrystallized domains, olivine porphyroclasts tend to display higher densities of subgrain boundaries than farther away (white arrows in Figure 6b). However, in most partially recrystallized peridotites, neoblasts overgrow the preexisting coarse-granular microstructure in a non-organized manner (Figures 3e and 3f). They are dispersed in a heterogeneous manner along the grain boundaries of olivine porphyroclasts, without forming neither a clear foliation nor core and mantle structures (Figures 3e, 6c, 6e, and S1). Strongly recrystallized peridotites contain irregular pockets of olivine neoblasts (Figure S1). Isolated olivine neoblasts have usually irregular shapes, but within recrystallized pockets, contacts between olivine neoblasts tend to be polygonal (Figures $6 \mathrm{~b}$ and $6 \mathrm{~d}$ ). The recrystallization front, that is, the contact between the recrystallized patch and the olivine porphyroclasts, is usually sinuous (Figure S1). In some strongly recrystallized peridotites ( $>20 \%)$, olivine neoblasts display 
tabular shapes (Figure 6f), with well-developed (010) and, sometimes, (021) faces (verified by EBSD). Olivine neoblasts have variable grain sizes within a sample and between samples. They are usually smaller than $1 \mathrm{~mm}$ (Figure 6), but may attain up to $2 \mathrm{~mm}$ in some peridotites (e.g., SAL16 or SAL18). Olivine porphyroclasts have always very irregular shapes, in particular when in contact with pyroxenes and high intragranular misorientations (Figure 6). Occasionally, orthopyroxene porphyroclasts are crosscut by seams of recrystallized olivine or display embayments filled by olivine neoblasts (black arrows in Figure 6d). In rare samples, as in SAL2, the tabular neoblasts have a shape-preferred orientation, marking a new foliation $\left(\mathrm{S}_{2}\right.$ in Figure 6e) oblique to the coarse-porphyroclastic fabric evidenced by the preferred orientation of the subgrains in olivine porphyroclasts $\left(\mathrm{L}_{1}\right.$ in Figure 6e).

Equigranular peridotites (Figures 3i, 3j, and 7) are characterized by recrystallized area fractions $\geq 40 \%$ and 2D area-weighted mean grain sizes $<1 \mathrm{~mm}$, except for 69SAL63a that has a coarser average grain size of $1.4 \mathrm{~mm}$ (Figure 4). As in the partially recrystallized peridotites, contacts between olivine neoblasts tend to be polygonal, but those with olivine porphyroclasts or pyroxenes are usually sinuous. In most samples, the olivine neoblasts have no shape-preferred orientation, but in SAL37b, 69SAL41a, GF5, and GF8, alignment of tabular olivine neoblasts results in a weak foliation (Figures 3i, 7a, and 7b). All samples preserve a few olivine porphyroclasts with very irregular shapes and frequent subgrains. In dunite PAL8, the porphyroclasts are oxidized, while the neoblasts are not (Figures $7 \mathrm{c}$ and $7 \mathrm{~d}$ ). Orthopyroxene occurs either as large- or intermediate-sized porphyroclasts with irregular shapes and sinuous boundaries (Figure 3j), where the embayments are filled by olivine (white arrows in Figures $7 \mathrm{e}$ and $7 \mathrm{f})$, or as small ( 500 $\mu \mathrm{m}$ wide) crystals with polygonal or interstitial-like shapes (Figure $7 \mathrm{~b}$ ). When present, clinopyroxene is smaller than orthopyroxene and occurs dispersed in the sample with interstitial-like shapes (Figure 3j).

\subsection{Mineral Chemistry: Major and Minor Elements}

Olivine in the peridotites is characterized by a wide range of compositions with $\mathrm{Mg} \#[\mathrm{Mg} \#=\mathrm{Mg} /(\mathrm{Mg}+\mathrm{Fe})]$ from 85 to 91.4. Coevolution of olivine modal content and $\mathrm{Mg \#}$ during partial melting may explain part of the data, but melt-rock reactions leading to either dunitization or refertilization are required to explain the Fe-rich olivine compositions ( $\mathrm{Mg} \#<89)$ in peridotites with highly variable olivine contents (Figure 8a). Very high melt-rock ratios are required to account for olivines with $\mathrm{Mg} \#<88$ (Bodinier \& Godard, 2014), suggesting that these peridotites might represent reacted wall rock of veins or dykes. There are no significant core-rim variations in Mg\#, except for one equigranular lherzolite, GF9 (Mg\# 88.8 in the rims and 89.9 in the cores). However, most Fe-rich peridotites show heterogeneity in olivine $\mathrm{Mg \#}$ at the thin section ( $\mathrm{mm}$ ) scale. There is no correlation between the microstructure and olivine Mg\# and Ni content. Ni contents in olivine vary from 2,700 to $4,560 \mathrm{ppm}$ (Table S1). The lowest Ni contents in olivines from harzburgites SAL35 and SAL10 are associated with the lowest $\mathrm{Mg} \#(<86)$, but there is no systematic correlation between $\mathrm{Mg \#}$ and $\mathrm{Ni}$ content. Most peridotites show $\mathrm{Ni}$ contents in olivine in the range 2,9503,300 ppm, in spite of a strong variation in Mg\# (88-91.4). The two dunites (PAL8, GF13), as well as coarse-granular harzburgite PAL1, have olivine with $\mathrm{Mg \#}<89$, but high Ni contents $(>3,850 \mathrm{ppm})$ in olivine. In some partially recrystallized peridotites (SAL3, SAL20, PAL1, GF4, GF9, PU5-6), olivine has lower $\mathrm{Ni}$ contents in the rims $(-4 \%$ to $-16 \%)$ relatively to the cores.

Orthopyroxene is enstatite with $\mathrm{Mg \#}$ ranging from 84.5 to 91.7, in equilibrium with $\mathrm{Mg \#}$ of olivine (Figure 8b). Clinopyroxene is Cr-rich diopside $\left(\mathrm{Cr}_{2} \mathrm{O}_{3}=0.36-1.7\right.$ wt.\%) with $\mathrm{Mg \#}$ ranging from 85.7 to 91.7. $\mathrm{Mg \#}$ in clinopyroxene does not show a unique correlation to the $\mathrm{Mg \#}$ in olivine (Figure 8c). Comparison of $\mathrm{Mg} \#$ between olivine, orthopyroxene, and clinopyroxene indicates equilibrium between olivine and orthopyroxene in all peridotites, but clinopyroxenes in disequilibrium in many partially recrystallized and equigranular peridotites (Figures $8 \mathrm{~b}$ and 8c). The Mg\# ranges and equilibrium states between olivine and pyroxenes observed in the present study (Figures $8 \mathrm{~b}$ and $8 \mathrm{c}$ ) are consistent with previous data in Hawaii peridotites (Bizimis et al., 2003; Goto \& Yokoyama, 1988; Sen, 1988; Sen et al., 1993). However, the present data set does not corroborate the correlation between Fe enrichment and grain size decrease previously described in Salt Lake peridotites by Goto and Yokoyama (1988). The most extreme Fe enrichment is observed in coarse-granular peridotites (Figures 8a to 8c).

Both orthopyroxene and clinopyroxene have variable but correlated $\mathrm{TiO}_{2}$ contents, ranging between $0.03-$ 0.25 and $0.05-1.3$ wt.\%, respectively (Table S1). In both minerals, $\mathrm{TiO}_{2}$ contents are anticorrelated with the Mg\#, with exception of coarse-granular lherzolite SAL6-25 that has pyroxenes with high Mg\# and 

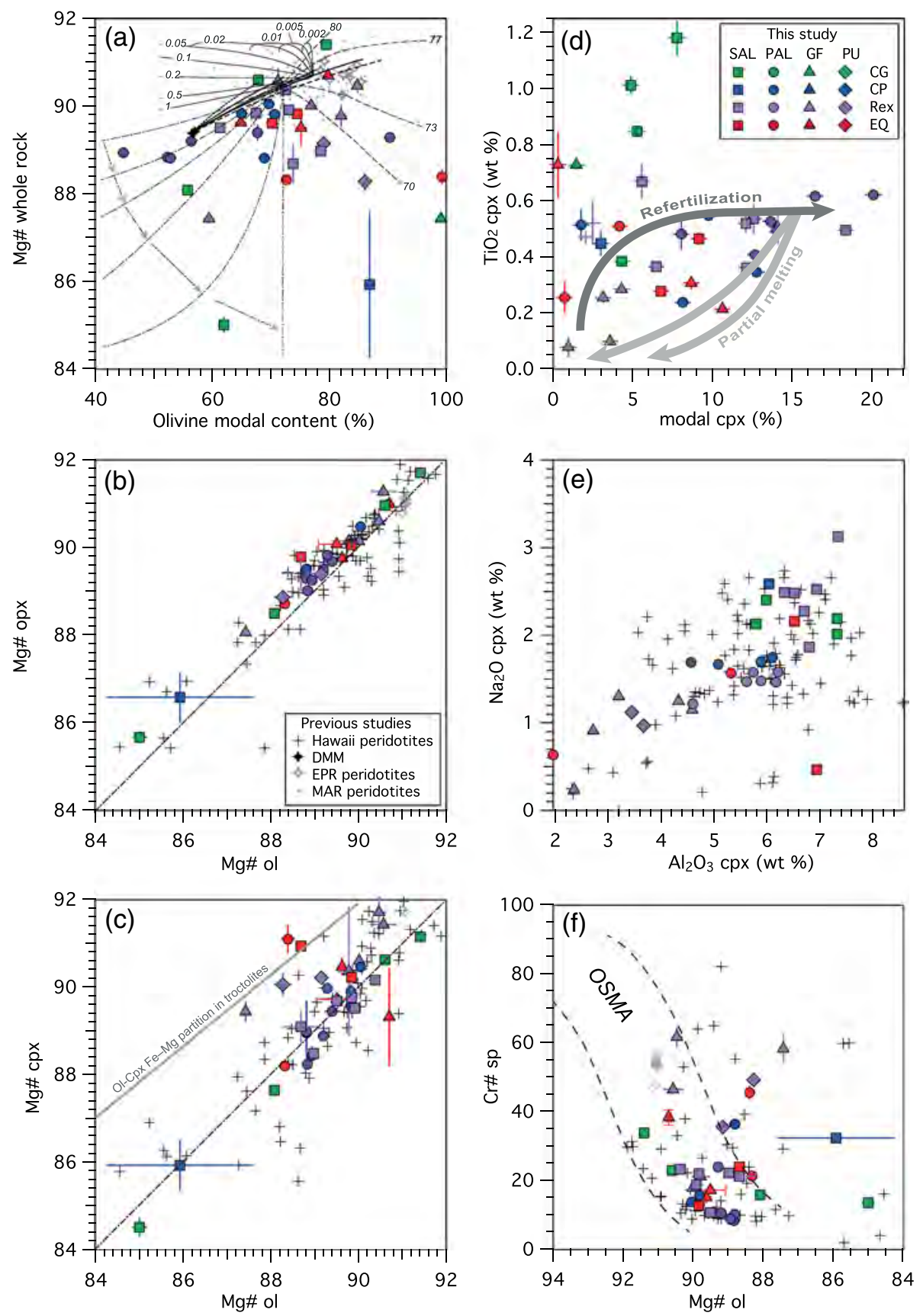

Figure 8. (a) Whole rock Mg\# versus olivine modal content. (b) Orthopyroxene Mg\# versus olivine Mg\#. (c) Clinopyroxene $\mathrm{Mg \#}$ versus olivine $\mathrm{Mg \#}$. (d) $\mathrm{TiO}_{2}$ content (wt. \%) in clinopyroxene versus clinopyroxene modal content compared to theoretical partial melting trends and to refertilization trends documented in the Lherz massif by Le Roux et al. (2007). (e) $\mathrm{Al}_{2} \mathrm{O}_{3}$ versus $\mathrm{Na}_{2} \mathrm{O}$ content (wt. \%) in clinopyroxene. (f) Spinel Cr\# versus olivine $\mathrm{Mg \#}$. For comparison, data from previous studies for Hawaii peridotites (Goto \& Yokoyama, 1988; Sen, 1988; Sen et al., 1993) are displayed in (b, c, e, f), data for abyssal peridotites from the East Pacific Rise (EPR) compiled by Warren (2016) in (a, f), and Fe-Mg partition between olivine and clinopyroxene in troctolites from Lissenberg and Dick (2008) in (c). Curves in (a) illustrate compositional evolutions predicted for partial melting (solid black lines) and reactive melt percolation (gray lines) in the mantle (Bodinier \& Godard, 2014). Dashed lines show olivine-forming reactions with melts with different $\mathrm{Mg} \#$ (numbers of the top of the curves), solid lines, precipitation of clinopyroxene and orthopyroxene with different mass ratios of crystallized minerals versus infiltrated melt (numbers of the top of the curves), and dotted dashed lines show multiple episodes of refertilization, starting with low Mg\# melts (74.5), in which the peridotites successively react with the evolved melt resulting from previous infiltration stage. OSMA stands for olivine-spinel mantle array (Arai, 1994). Error bars represent the variability of compositions within a sample. 
$\mathrm{TiO}_{2}$ contents and coarse-porphyroclastic harzburgite SAL10 that shows strong Fe enrichement, but moderate $\mathrm{Ti}$ enrichment in pyroxenes. The highest $\mathrm{TiO}_{2}$ contents are observed in coarse-granular peridotites; they are not associated with modal enrichment in clinopyroxene (Figure 8d). In contrast, coarse-porphyroclastic, partially recrystallized, and equigranular peridotites show a rough positive correlation between clinopyroxene modal and $\mathrm{TiO}_{2}$ contents (Figure 8d), but the latter are buffered at $\leq 0.75 \mathrm{wt} . \%$, consistent with refertilization trends in the Lherz peridotite massif (Le Roux et al., 2007). There is no correlation between $\mathrm{Cr}_{2} \mathrm{O}_{3}$ contents and $\mathrm{Mg} \#$ in clinopyroxenes. $\mathrm{Na}_{2} \mathrm{O}$ and $\mathrm{Al}_{2} \mathrm{O}_{3}$ contents in clinopyroxene are roughly anticorrelated with $\mathrm{Mg}$ \#, whereas $\mathrm{CaO}$ shows a gross positive correlation. Clinopyroxene from SAL peridotites has on average higher $\mathrm{Al}_{2} \mathrm{O}_{3}, \mathrm{Na}_{2} \mathrm{O}$, and $\mathrm{Cr}_{2} \mathrm{O}_{3}$ and lower $\mathrm{CaO}$ contents than peridotites from other localities (Figure 8e and Table S1), similar to previous data for Oahu peridotites (Bizimis et al., 2003; Sen, 1988; Sen et al., 1993).

Spinels show a wide range of compositions (Table S1) with anticorrelated $\mathrm{Mg \#}$ and $\mathrm{Cr} \#$ ranging between 12.6-75.3 and 8.4-61.7, respectively. Al-rich, fertile compositions predominate (Figure 8f). Some samples, independent of microstructural type or locality, display olivines enriched in $\mathrm{Fe}$, spinels enriched in $\mathrm{Cr}$, or both, relatively to the olivine-spinel mantle array (OSMA; Arai, 1994; Figure 8f). $\mathrm{Cr}_{2} \mathrm{O}_{3}$ contents in spinel and clinopyroxene are positively correlated in most samples. $\mathrm{TiO}_{2}$ contents in spinel range between $0.08 \mathrm{wt} . \%$ and $1 \mathrm{wt} . \%$, except in dunite PAL8 and in the dunitic and harzburgitic layers of sample GF13C, which have contents of $1.9 \mathrm{wt} . \%, 3.5 \mathrm{wt} . \%$, and $4.7 \mathrm{wt} . \%$, respectively, consistent with Ti enrichment in spinel during dunite-forming reactions (Kelemen \& Dick, 1995).

Pyroxenite mineral compositions are consistent with previous data on garnet-spinel pyroxenites from SAL (Keshav et al., 2007; Sen, 1988). Mg\# in olivine range from 75-77 in the clinopyroxenites SAL7 and SAL14 to 82.8 in the websterite SAL33 (Table S1). Clinopyroxene and orthopyroxene are in equilibrium with olivine. $\mathrm{TiO}_{2}$ and $\mathrm{Cr}_{2} \mathrm{O}_{3}$ contents in clinopyroxene are $0.7 \mathrm{wt} . \%$ and $0.31 \mathrm{wt} . \%$ in the websterite and $1.1-$ 1.3 wt.\% and $<0.06$ wt.\% in the clinopyroxenites. Garnet is $\mathrm{Pyr}_{56} \mathrm{Alm}_{31} \mathrm{Gro}_{13}$ in the clinopyroxenites and $\mathrm{Pyr}_{64} \mathrm{Alm}_{23} \mathrm{Gro}_{13}$ in the websterite SAL33.

\subsection{Trace Element Compositions of Orthopyroxene, Clinopyroxene, and Garnet}

The trace element composition of clinopyroxene and garnet from the Salt Lake and Pali peridotites and pyroxenites analyzed in the present study (Figure 9) overlaps that of previously studied xenoliths from these localities (Bizimis et al., 2003, 2007; Sen et al., 1993). Although a limited number of samples were analyzed, it sampled almost the entire range of observed compositions.

Salt Lake clinopyroxenes are characterized by systematic light Rare Earth Element (LREE) enrichment in both peridotites and pyroxenites. In peridotites (Figure 9a), clinopyroxenes commonly have convex upward chondrite-normalized REE patterns $\left[(\mathrm{La} / \mathrm{Nd})_{N}=0.6-0.9 ;(\mathrm{Sm} / \mathrm{Yb})_{N}=2.3-19.8 ; N=\right.$ normalized to C1chondrite; Sun \& McDonough, 1989], variably depleted heavy REE (HREE) compositions $\left(\mathrm{Yb}_{N}=1.2-8.5\right)$, and variable $\mathrm{Zr}$-Hf anomalies relative to middle REE (MREE) $[\mathrm{Zr}(-\mathrm{Hf}) / \mathrm{Sm}=0.3-1.8 \times$ primitive mantle; Sun \& McDonough, 1989]. LREE enrichment is generally stronger and HREE depletion less prominent in partially recrystallized peridotites (Figure 9a). Partially recrystallized lherzolites SAL16 and SAL6-58 have distinct clinopyroxene compositions with selective LREE enrichments relative to flatter MREE to HREE segments $\left[(\mathrm{La} / \mathrm{Nd})_{N}=1.6-2.6 ;(\mathrm{Sm} / \mathrm{Yb})_{N}=0.9-1.3\right]$ and systematic negative $\mathrm{Zr}$-Hf anomalies relative to REE [Zr(-Hf)/Sm = 0.3-0.7 $\times$ primitive mantle; Sun \& McDonough, 1989].

Clinopyroxenes in Salt Like pyroxenites (Figure 9c) also show these two patterns. Clinopyroxenites SAL7 and SAL14 have convex upward chondrite-normalized REE patterns $\left[(\mathrm{La} / \mathrm{Nd})_{N}=0.6 ;(\mathrm{Sm} / \mathrm{Yb})_{N}=8-\right.$ 25.7] and depleted HREE $\left(\mathrm{Yb}_{N}=0.9-2.9\right)$, while websterite SAL33 displays flatter REE patterns [(La/ $\left.\mathrm{Nd})_{N}=0.9-1 ;(\mathrm{Sm} / \mathrm{Yb})_{N}=1.9-2\right]$. These compositions indicate extensive clinopyroxene reequilibration with, and/or precipitation after, LREE-enriched melts. Orthopyroxenes in Salt Lake peridotites and in websterite SAL33 have relatively homogeneous REE patterns characterized by a steady decrease from HREE to $\operatorname{LREE}\left[(\mathrm{Ce} / \mathrm{Yb})_{N}=0.1-0.5\right]$. Their compositions are similar or slightly enriched relative to calculated values of depleted mid-oceanic ridge basalts (MORB) mantle (DMM) orthopyroxene (D'Errico et al., 2016). These characteristics support extensive reequilibration with LREE-rich melts having cogenetic links through melt-rock reaction processes. Coupled trace element and isotopic studies showed that peridotites with convex upward REE patterns in clinopyroxenes equilibrated with the melts forming the late Honolulu alkaline olivine basalt series concurrently with the crystallization of garnet-spinel pyroxenites, which explains their 

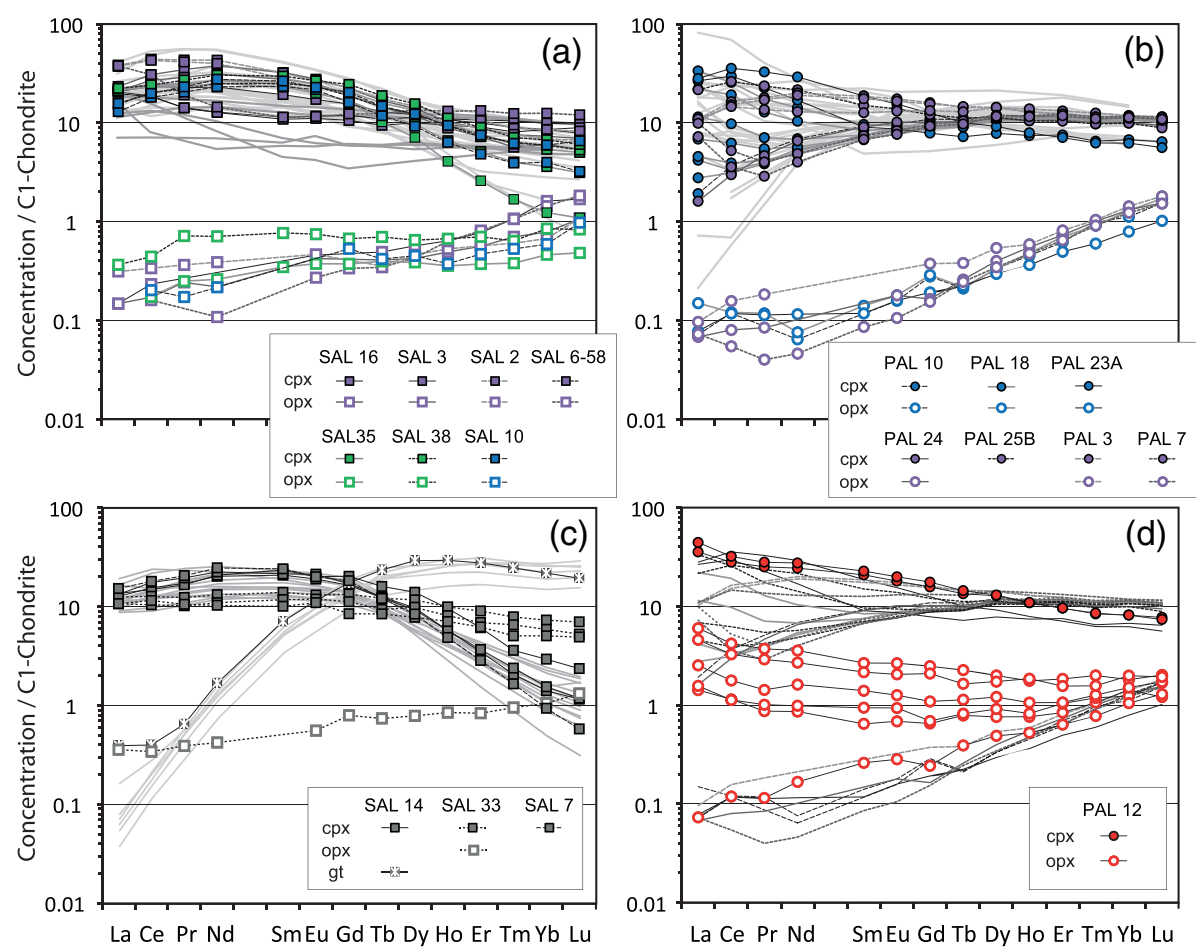

Figure 9. Rare Earth Element (REE) compositions of clinopyroxene, orthopyroxene, and garnet measured in the studied (a) SAL peridotites, (c) SAL pyroxenites, and (b, d) PAL peridotites. REE compositions are normalized to C1-chondrites (Sun \& McDonough, 1989). In (a), (b), and (d), REE spectra for coarse-granular peridotites are marked in green, for coarse-porphyroclastic peridotites in blue, for partially recrystallized peridotites in violet, and for equigranular peridotites in red. In (d), the composition of pyroxenes in equigranular peridotite PAL12 is compared to those of the other PAL peridotites (same line patterns as in b). The REE compositions of clinopyroxene in (a) and (b) are compared to published data for peridotites from Salt Lake Crater (light gray and dark gray patterns for the least and most metasomatized samples) and Pali (light gray patterns), respectively. REE compositions of clinopyroxene and garnet in (c) are compared to published compositions of garnet (light gray patterns) and clinopyroxene (dark gray patterns) in Salt Lake pyroxenites. Data from Bizimis et al. (2003, 2007) and Sen (1988).

variable HREE depletion, while peridotites with flat HREE patterns equilibrated with melts formed by a clinopyroxene dissolution-orthopyroxene precipitation reaction at decreasing melt mass triggered by the percolation of the primitive end-members of these alkaline olivine basalts into a moderately depleted oceanic mantle lithosphere (Bizimis et al., 2003).

Clinopyroxenes from the Pali peridotites (Figure 9b) have spoon-shaped patterns with convex upward to flat distributions of MREE to HREE typical of residual clinopyroxenes in abyssal peridotites [( $\mathrm{Sm} / \mathrm{Yb})_{N}=0.6-$ 1.7; e.g., D'Errico et al., 2016], a restricted range of HREE compositions $\left(\mathrm{Yb}_{N}=9.9-12.8\right)$, and extremely variable LREE fractionations, sometimes within a single sample $\left[(\mathrm{La} / \mathrm{Nd})_{N}=0.25-2.35 ;(\mathrm{La} / \mathrm{Nd})_{N}=0.5-2.1\right.$ in PAL18]. The most LREE-enriched clinopyroxenes are HREE depleted $\left[(\mathrm{Sm} / \mathrm{Yb})_{N}=1.3-3 ; \mathrm{Yb}_{N}=6.2-8.5\right]$ (cf. coarse-porphyroclastic peridotite PAL23A and equigranular peridotite PAL12 in Figures 9b and 9d). Previous studies interpreted these compositions as indicative of small degrees of interaction between a LREE-rich melt, probably linked to the rejuvenated-stage Honolulu alkaline olivine basalt series, and oceanic lithosphere peridotites (Bizimis et al., 2003; Sen et al., 1993). Pali orthopyroxenes are homogeneous and characterized by a steady decrease from HREE to LREE $\left[(\mathrm{Ce} / \mathrm{Yb})_{N}=0.04-0.15\right]$, with compositions overlapping that of orthopyroxenes from abyssal peridotites (e.g., D'Errico et al., 2016). This indicates that they were little affected by melt-rock interactions, except for equigranular peridotite PAL12. In this sample (Figure 9d), orthopyroxenes have highly variable compositions and fractionations $\left[(\mathrm{Ce} / \mathrm{Yb})_{N}=0.1-2.3\right]$, which, together with the LREE-rich composition of the clinopyroxenes, support that this equigranular peridotite represents the most reacted end-member among the studied Pali peridotites. 


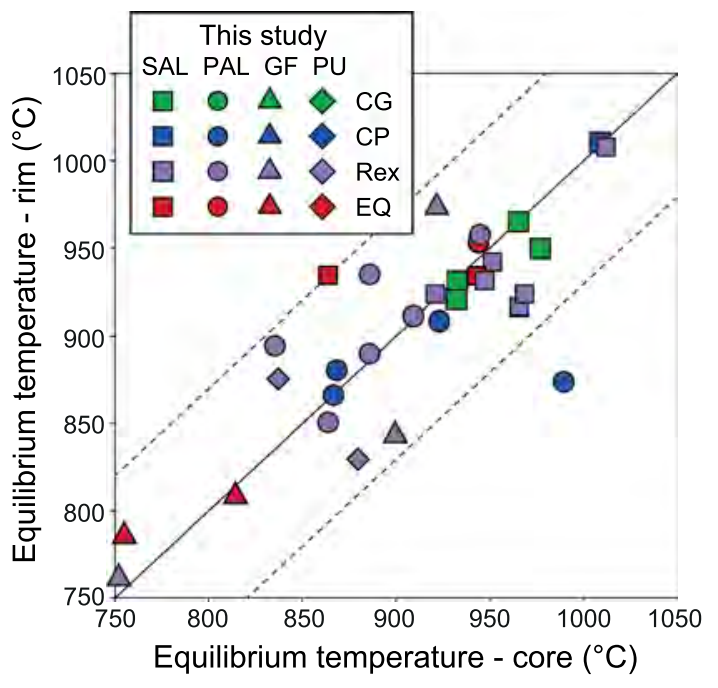

Figure 10. Core versus rim equilibrium temperatures predicted by the two-pyroxene thermometer of Brey and Koehler (1990). Dashed lines define the $\pm 70^{\circ}$ uncertainty of the data.

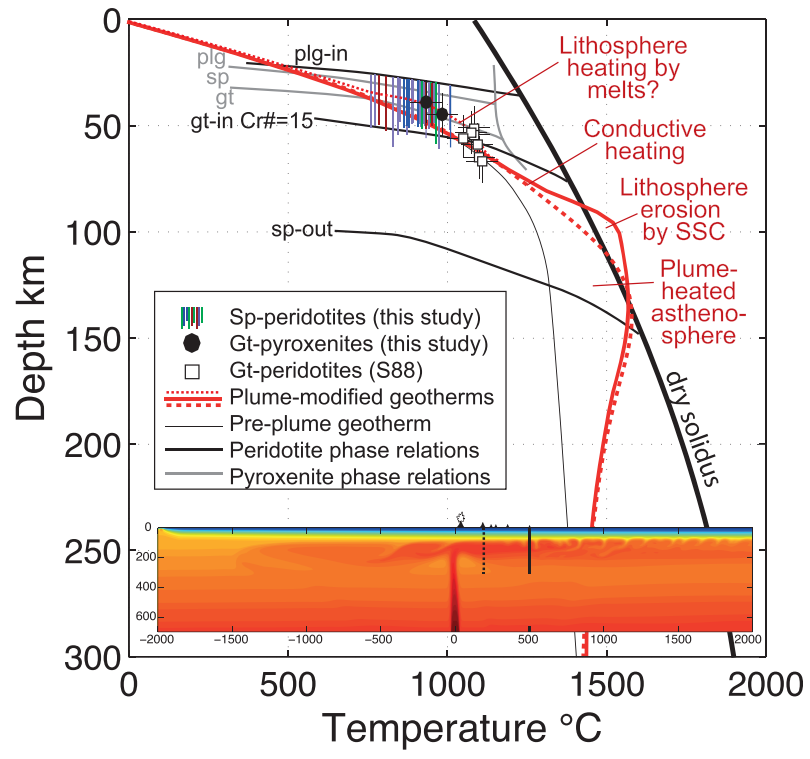

Figure 11. Depth versus temperature diagram comparing the equilibrium conditions estimated for the Hawaii mantle peridotites and pyroxenites to geotherms predicted downstream of the impact point for a mantle plume with a $325^{\circ} \mathrm{C}$ thermal anomaly impacting a $90 \mathrm{~km}$ thick plate, based on the model presented in the inset at the bottom of the figure (Agrusta et al., 2015). As no barometers are available for spinel peridotites, pressure ranges are presented as bars, based on the absence of plagioclase and of garnet in the peridotites and their $\mathrm{Cr} \#$. The color of the bars indicates the microstructure. Phase transitions after O'Neill (1981) and Klemme (2004). Dry solidus after Ringwood (1975). White squares (S88) indicate Salt Lake garnet peridotite thermobarometry data from Sen (1988).

\subsection{Geothermometry}

Equilibrium temperatures in the peridotites calculated using the Brey and Koehler (1990) two-pyroxene geothermometer vary between $750^{\circ} \mathrm{C}$ and $1010^{\circ} \mathrm{C}$ (Table 1). Comparison between temperatures calculated using core and rim compositions reveals that most samples are in equilibrium (Figure 10). Partially recrystallized peridotites GF2A, PAL15, PALD4, and PU4A and equigranular peridotite 69SAL63A display higher rim temperatures relative to core ones, which might indicate incomplete reequilibration in response to heating, whereas partially recrystallized peridotites SAL3 and SAL18 show lower rim temperatures relative to core ones. However, most core-rim variations are within the $\pm 70^{\circ} \mathrm{C}$ of uncertainty of the thermometer. Only coarse-porphyroclastic peridotite PAL18 shows significantly lower rim temperatures, denoting cooling. Temperatures estimated using the $\mathrm{Ca}$ and $\mathrm{Al}$ in orthopyroxene thermometers (Table 1) are similar or higher (most samples) than those obtained with the two-pyroxene geothermometer. The higher temperatures for orthopyroxene thermometers suggest non-complete achievement of equilibrium for the slower diffusing $\mathrm{Ca}$ and $\mathrm{Al}$ (relative to $\mathrm{Fe}$ and $\mathrm{Mg}$ ) in a global cooling history. The higher proportion of non-equilibrated samples when the $\mathrm{Al}$ in orthopyroxene thermometer is considered is consistent with the slower diffusion rates of $\mathrm{Al}$ relatively to Ca.On average, Salt Lake peridotites show higher equilibrium temperatures (Figure 10), which may imply equilibration at higher depths. Grove Farm and Pu'uwai xenoliths display on average lower equilibrium temperatures, suggesting they may sample shallower lithospheric levels. An exception is the partially recrystallized peridotite GF2A, which is equilibrated at $>900^{\circ} \mathrm{C}$. Interestingly, this sample is among those showing a corerim variation that could denote a late heating event.

The garnet and spinel pyroxenites SAL14 and SAL33 have equilibrium temperatures and pressures of $1000^{\circ} \mathrm{C} / 1.45 \mathrm{GPa}$ and $937^{\circ}$ $\mathrm{C} / 1.25 \mathrm{GPa}$. These pressures and temperatures are on the lower range of the previous thermobarometric determinations on Salt Lake garnet-bearing xenoliths (Keshav et al., 2007; Sen, 1988). Comparison of these data with geotherms predicted by models simulating a plume with a $325^{\circ} \mathrm{C}$ temperature anomaly impacting a $90 \mathrm{~km}$ thick oceanic plate (Agrusta et al., 2015) shows that the equilibrium temperatures of the Salt Lake garnet and spinel pyroxenites are 100$150^{\circ}$ hotter than the modeled geotherm (Figure 11), suggesting additional heating of the lithospheric mantle by melt percolation and crystallization (latent heat). Plotting the equilibrium tempera-tures obtained for the spinel peridotites on the modeled conductive geotherm would imply that they are derived from depths of 35-55 $\mathrm{km}$. Use of the perturbed geotherm that fits the garnet and spinel pyroxenite thermobarometric data lowers the maximum depth to 45 $\mathrm{km}$.

\subsection{Crystal ${ }^{-}$Preferred Orientations}

Figure 12 displays $\mathrm{CPO}$ of olivine, orthopyroxene, and clinopyroxene for samples representative of the different microstructural types and, for the partially recrystallized and equigranular peridotites, variable recrystallized area fractions. CPO data for all studied peridotites are presented in Figure S2. 


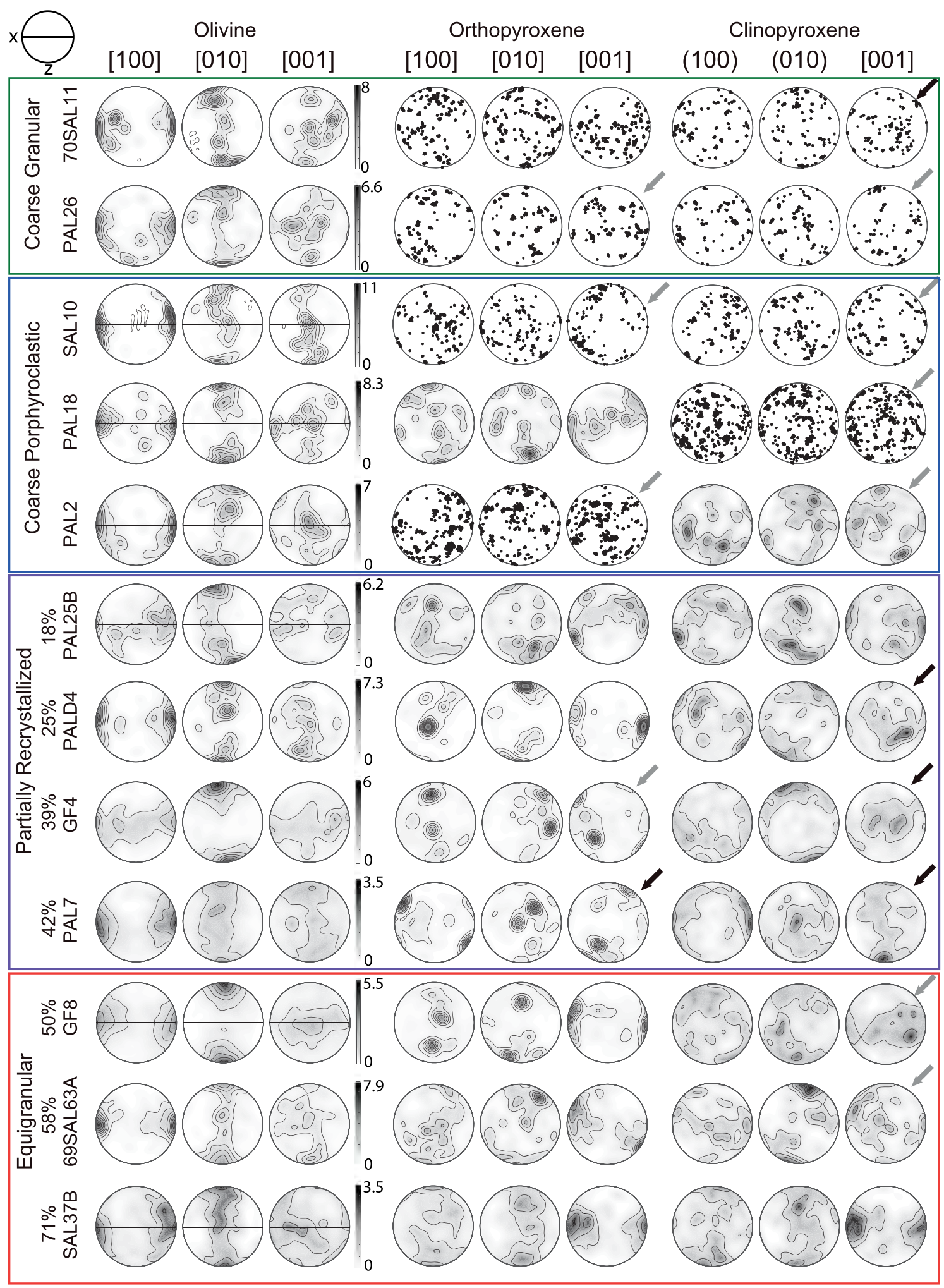

Figure 12. Representative crystal-preferred orientations (CPOs) of olivine, orthopyroxene, and clinopyroxene for the different microstructural types and, for partially recrystallized and equigranular peridotites, different recrystallized fractions (\% on the top of the sample names). Lower hemisphere stereographic projections with contours at one multiple of uniform distribution intervals. Black arrows indicate pyroxene CPOs not correlated with the olivine ones and gray arrows mark those that are partially correlated (see text for definition of the correlation criterion). Very strong maxima in pyroxenes CPO result from the presence of a few coarse grains in the analyzed area and are not statistically representative. When $<100$ grains were measured, data are presented as points, instead of density contoured. 

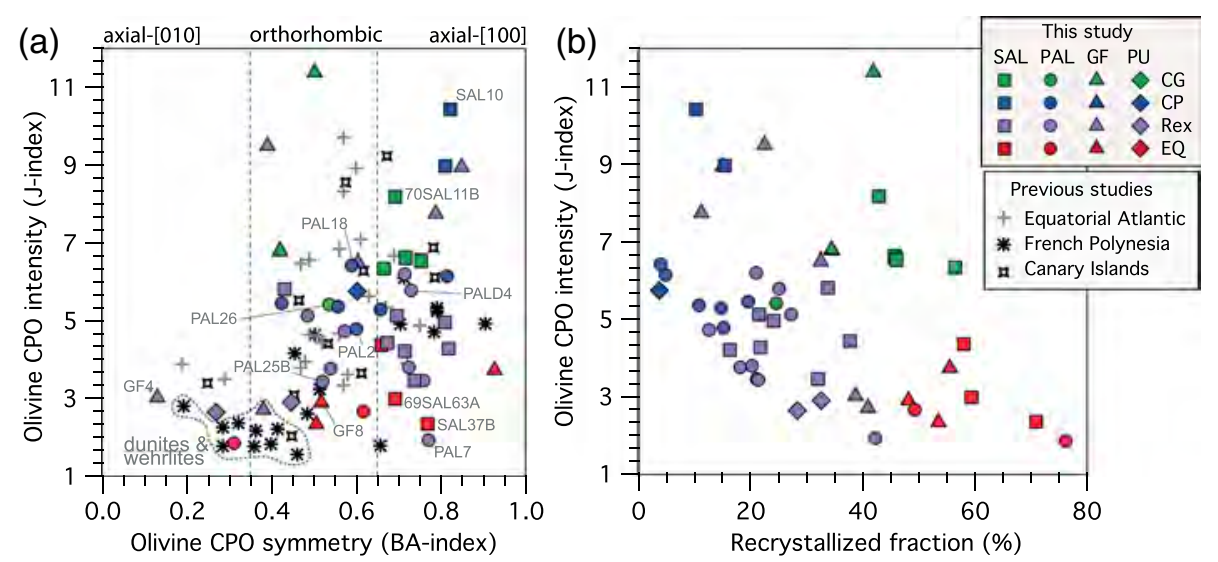

Figure 13. (a) Olivine CPO symmetry (BA index) versus CPO strength (J index) in Hawaii peridotites (data presented in Table 2). (b) Olivine CPO strength (J index) as a function of the recrystallized fraction. In (a), labels indicate the samples with CPO presented in Figure 12. J and BA indexes for mantle xenoliths from Fernando de Noronha (Liu et al., 2019) and Canary Islands (Vonlanthen et al., 2006) in the Atlantic Ocean and French Polynesia in the Pacific Ocean (Tommasi et al., 2004) recalculated using with the same CPO analysis parameters as in the present study are shown for comparison in (a).

Olivine CPO strength and patterns vary in a continuous manner among the different microstructural types (Figure 13). Coarse-granular and coarse-porphyroclastic peridotites have strong olivine CPO (J index $\geq 5$ ) with orthorhombic to axial-[100] patterns, but coarse-porphyroclastic peridotites have on average CPO patterns with a stronger axial-[100] tendency $(0.59<$ BA index $<0.82)$ than coarse-granular peridotites $(0.4<$ BA index $<0.76)$. In partially recrystallized and equigranular peridotites, increase in the recrystallized area fraction is associated with decrease in the CPO strength and with increase in the variability in the olivine CPO symmetry (Figure 13). These peridotites have olivine CPO symmetries ranging from axial-[010] to axial-[100] $(0.27<$ BA index < 0.93). However, orthorhombic to axial-[100] patterns predominate, because the CPOs of the recrystallized grains are more dispersed, but similar to the CPO of the porphyroclasts (Figure S3). In all samples where a shape-preferred orientation of olivine marks the lineation and foliation, the maximum of olivine [100] axes is subparallel to the lineation and the maximum of [010] is normal to the foliation (Figure 12).

CPOs of both pyroxenes are much more dispersed than the olivine CPO (Figures 12 and S2). Nevertheless, orthopyroxene displays in many samples a CPO correlated with that of olivine, with concentration of $[001]_{\mathrm{opx}}$ subparallel to the $[100]_{\mathrm{ol}}$ maximum and weaker maxima of $[100]_{\mathrm{opx}}$ or $[010]_{\mathrm{opx}}$ (or both) subparallel to the $[010]_{\mathrm{ol}}$ maximum. In some samples, the orthopyroxene CPO is only partially correlated to the olivine $\mathrm{CPO}$, meaning that other orientations, often at high angle to the maxima described above, are also volumetrically important (gray arrows in Figure 11). Finally, in a few samples, the orthopyroxene CPO is uncorrelated with the olivine CPO, displaying a strong obliquity to it (black arrow in Figure 12). Coarse-porphyroclastic peridotite PAL18 (also PAL10, cf. Figure S2) has a correlated orthopyroxene CPO, but it shows a girdle of $[001]_{\text {opx }}$ in a plane oblique to the foliation that contrasts with the point concentration of $[100]_{\mathrm{ol}}$. The degree of correlation between the orthopyroxene and the olivine CPO decreases on average with increasing recrystallized fraction, but not in a simple linear trend. For instance, equigranular peridotites in Figure 12 show orthopyroxene CPO rather well correlated with the olivine CPO.

Clinopyroxene CPOs tend to be even weaker than orthopyroxene CPOs. They are often poorly or not correlated to the olivine CPO (gray and black arrows in Figure 12). Yet, some samples, like the weakly recrystallized peridotite PAL25B and equigranular peridotite SAL37B, show CPO characterized by a $[001]_{\mathrm{cpx}}$ maximum subparallel to the $[100]_{\mathrm{ol}}$ and $[001]_{\mathrm{opx}}$ maxima, that is, a clinopyroxene CPO well correlated with both the olivine and orthopyroxene CPO. Other peridotites, like coarse-porphyroclastic peridotite PAL2, show similar clinopyroxene and orthopyroxene $\mathrm{CPO}$, but that are only partially correlated with the olivine CPO (Figure 12). 

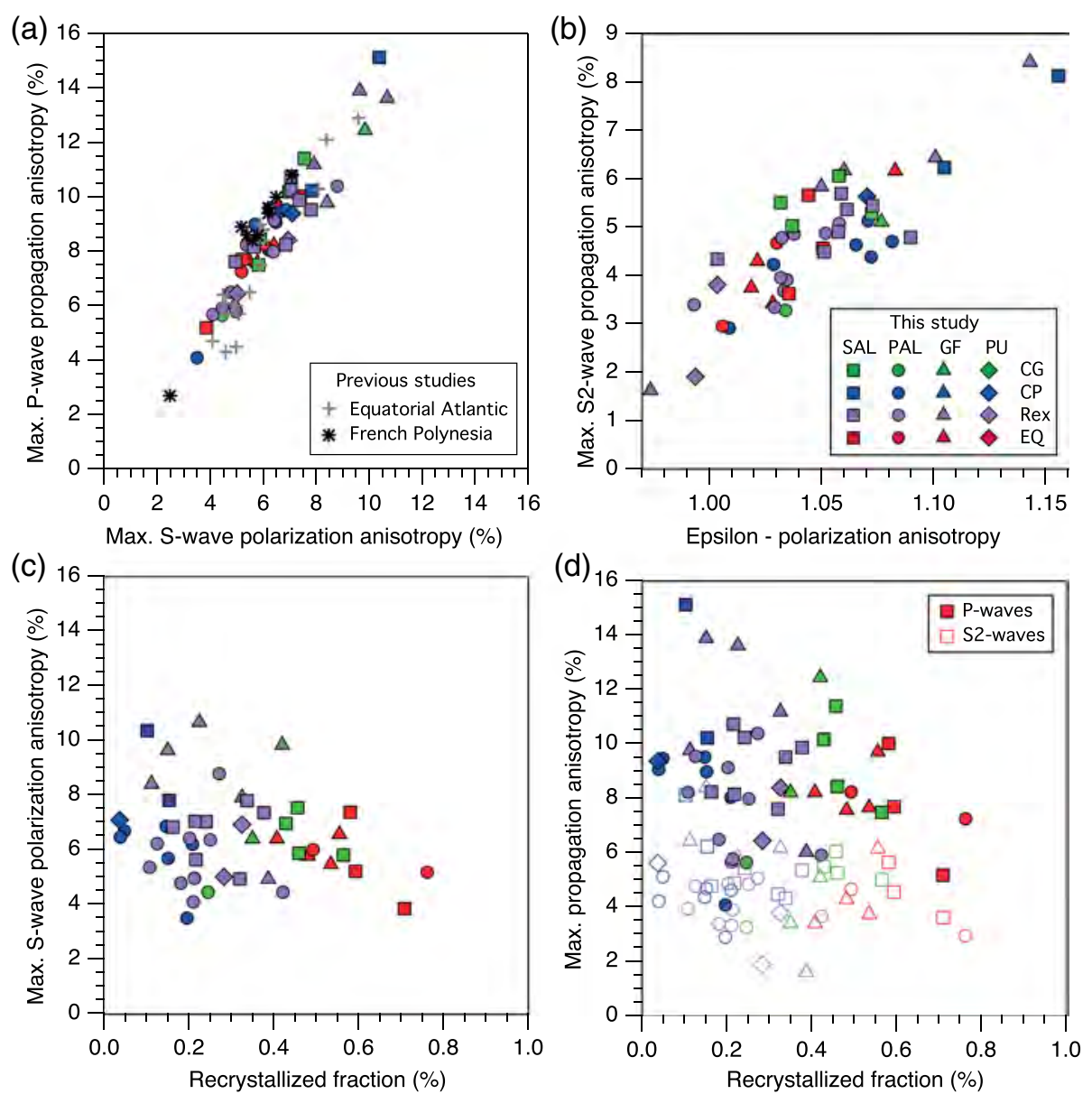

Figure 14. Seismic anisotropy of individual samples calculated for a temperature of $1000^{\circ} \mathrm{C}$ and a pressure of $1.45 \mathrm{GPa}$. (a) Maximum $S$ wave polarization anisotropy versus maximum $P$ wave propagation anisotropy. For comparison, data for mantle xenoliths from French Polynesia in the Pacific Ocean (Tommasi et al., 2004) and Fernando de Noronha in the equatorial Atlantic (Liu et al., 2019) are presented. (b) Maximum propagation anisotropy of S2 waves and epsilon ( $\xi$ ) values, which correspond to the azimuthal anisotropy of Rayleigh waves and the polarization anisotropy of surface waves, respectively, if the flow direction and the flow plane are horizontal, as expected in a "normal" oceanic lithospheric mantle. (c) Maximum $S$ wave polarization anisotropy versus recrystallized fraction. (d) Maximum $P$ - and S2 waves propagation anisotropies versus recrystallized fraction.

\subsection{Seismic Properties}

We calculated the seismic properties of all studied peridotites at $1000^{\circ} \mathrm{C}$ and $1.45 \mathrm{GPa}$, which correspond to the equilibrium conditions of the garnet-spinel pyroxenite SAL33 (Figure 11). The density, elastic constants, and seismic properties for all individual samples are presented in Tables S3 and S4. The similarity in olivine CPO symmetry (predominance of orthorhombic patterns) results in similar seismic velocity and anisotropy patterns for the majority of the studied Hawaii xenoliths. The intensities of the maximum propagation anisotropy of $P$ and of the maximum polarization anisotropy of $S$ waves are positively correlated (Figure 14a). The maximum propagation anisotropy of S2 waves and $\xi$ values, which correspond to the azimuthal anisotropy of Rayleigh waves and the polarization anisotropy of surface waves if the flow direction and the flow plane are horizontal, as expected in a "normal" oceanic lithospheric mantle (Rümpker et al., 1999; Tommasi, 1998), are also correlated (Figure 14b). However, the intensity of these anisotropies varies significantly among the samples (Figures 14a and 14b) due to changes in both the strength of the olivine CPO and the olivine modal content. Variability in the intensity of seismic anisotropy is observed within all microstructural types, but equigranular peridotites have on average lower anisotropies (Figures 14c and 14d). Seismic anisotropy intensity is variable in all well-sampled localities (for Pu'uwai, we had access to few 
Table 3

Average Seismic Properties for Oahu and Kauai Calculated at Different Temperatures and Pressures

\begin{tabular}{|c|c|c|c|c|c|c|c|c|c|c|c|c|}
\hline Locality & $\begin{array}{c}\text { Temperature } \\
\left({ }^{\circ} \mathrm{C}\right)\end{array}$ & $\begin{array}{l}\text { Pressure } \\
(\mathrm{GPa})\end{array}$ & $\begin{array}{c}\mathrm{AVp} \\
(\mathrm{km} / \mathrm{s})\end{array}$ & $\begin{array}{l}\text { Vp Mean } \\
(\mathrm{km} / \mathrm{s})\end{array}$ & $\begin{array}{c}\text { AVs } \\
(\%)\end{array}$ & $\begin{array}{l}\text { Vs Mean } \\
(\mathrm{km} / \mathrm{s})\end{array}$ & $\begin{array}{c}\text { AVs1 } \\
(\%)\end{array}$ & $\begin{array}{l}\text { Vs1 Mean } \\
(\mathrm{km} / \mathrm{s})\end{array}$ & $\begin{array}{c}\text { AVs2 } \\
(\%)\end{array}$ & $\begin{array}{l}\text { Vs2 Mean } \\
(\mathrm{km} / \mathrm{s})\end{array}$ & $\begin{array}{c}\mathrm{Vp} / \mathrm{Vs} 1 \\
\text { mean }\end{array}$ & $\xi$ \\
\hline Oahu & 230 & 0.28 & 7.9 & 8.2 & 4.7 & 4.7 & 2.4 & 4.8 & 3.9 & 4.7 & 1.69 & 1.05 \\
\hline Oahu & 900 & 1.45 & 7.9 & 7.9 & 5.0 & 4.5 & 2.7 & 4.6 & 4.2 & 4.4 & 1.71 & 1.05 \\
\hline Oahu & 1000 & 1.45 & 7.9 & 7.8 & 5.2 & 4.5 & 2.7 & 4.6 & 4.3 & 4.4 & 1.71 & 1.05 \\
\hline Kauai & 230 & 0.28 & 8.9 & 8.2 & 5.8 & 4.7 & 3.6 & 4.8 & 4.4 & 4.6 & 1.69 & 1.04 \\
\hline Kauai & 900 & 1.45 & 8.9 & 7.9 & 6.0 & 4.5 & 3.8 & 4.6 & 4.6 & 4.4 & 1.71 & 1.05 \\
\hline Kauai & 1000 & 1.45 & 8.9 & 7.8 & 6.1 & 4.5 & 3.9 & 4.6 & 4.7 & 4.4 & 1.71 & 1.05 \\
\hline
\end{tabular}

Note. AVp, maximum $P$ wave propagation anisotropy; AVs, maximum $S$ wave polarization anisotropy; AVs1, maximum propagation anisotropy for the fast $S$ wave; AVs2, maximum propagation anisotropy for the slow $S$ wave; $\xi$ (epsilon), N/L $=\left(1 / 8^{*}[\mathrm{C} 11+\mathrm{C} 22]-1 / 4 * \mathrm{C} 12+\mathrm{C} 66 / 2\right) /([\mathrm{C} 44+\mathrm{C} 55] / 2)$ assuming a horizontal foliation.

samples), but average maximum anisotropies are slightly higher for Grove Farm and Salt Lake peridotites relative to Pali (Figure 14).

Since seismic waves average properties over large volumes (tens of kilometers wide), we calculated average seismic properties beneath Oahu and Kauai by averaging the elastic properties of all Salt Lake and Pali peridotites and of all Grove Farm and Pu'uwai peridotites, respectively (Table 3). Seismic anisotropy patterns beneath both islands are similar. Thus, we only present the pattern for Oahu, which was calculated based on a larger number of samples (Figure 15). Average seismic properties beneath Oahu are typical of upper mantle rocks deformed under high-temperature, low-pressure conditions. $P$ wave velocities range between 7.6 and $8.22 \mathrm{~km} / \mathrm{s}$, with a mean at $7.8 \mathrm{~km} / \mathrm{s}$. $P$ wave anisotropy is strong (up to $7.9 \%$ ), with the fastest propagation velocities parallel to the flow direction and the slowest velocities normal to the flow plane. $S$ wave polarization anisotropy is also strong (up to 5.2\%), with fast polarization parallel to the flow direction. High $S$ wave polarization anisotropy is observed for waves propagating at high angle to the flow direction and low angle to the flow (XY) plane, whereas apparent isotropy is observed for waves propagating within $\pm 30^{\circ}$ of the flow direction along the XZ plane. If both the flow direction and the flow plane are horizontal, as expected in the Pacific lithospheric mantle (Rümpker et al., 1999; Tommasi, 1998), Love waves will show weak azimuthal anisotropy $(<2 \%)$ with a $90^{\circ}$ periodicity and fastest propagation $(4.6 \mathrm{~km} / \mathrm{s})$ at $45^{\circ}$ to the flow direction and Rayleigh waves will display strong azimuthal anisotropy (4.3\%) with a $180^{\circ}$ periodicity and fastest propagation $(4.5 \mathrm{~km} / \mathrm{s})$ parallel to the flow direction. Surface waves polarization anisotropy will vary as a function of the propagation azimuth, with an azimuthally averaged $\xi={ }^{\nu_{S H}}{ }_{v_{S V^{2}}}$ of 1.05 .

To quantify the effects of the changes in microstructure and associated CPO on the seismic properties, we calculated average seismic properties for each microstructural type (Figure S4). Average patterns for coarse-granular, partially recrystallized, and equigranular peridotites are almost identical to the one presented in Figure 15. Coarse-porphyroclastic peridotites display a more hexagonal pattern with a fast symmetry axis, due to the higher proportion of axial-[100] olivine CPO within this microstructure. However, this

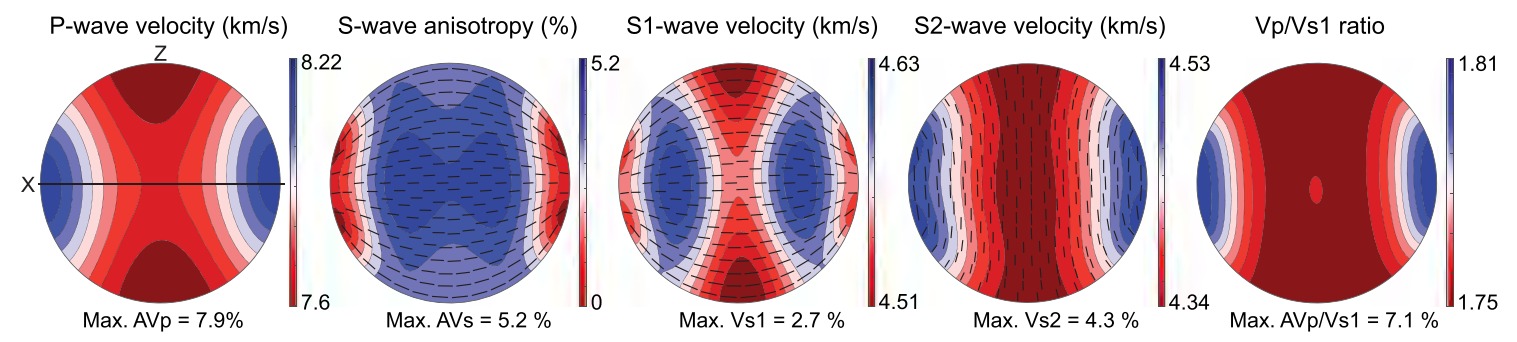

Figure 15. Average seismic properties for Oahu (Salt Lake and Pali) peridotites at $1000^{\circ} \mathrm{C}$ and $1.45 \mathrm{GPa}$. From left to right: $P$ wave velocities $(\mathrm{Vp}$; km/s), $S$ wave polarization anisotropy [AVs $=200 \times(\mathrm{Vs} 1-\mathrm{Vs} 2) /(\mathrm{Vs} 1+\mathrm{Vs} 2)$ in $\%$, the bars indicate the orientation of the fast S1 wave polarization plane, S1 wave velocities (Vs1; km/s), S2 wave velocities (Vs2; km/s), and Vp/Vs1 ratio. Lower hemisphere stereographic projections presenting the variation of the property as a function of the propagation direction relative to the structural reference frame (flow direction $\mathrm{X}$ and normal to the flow plane $\mathrm{Z}$ ). 
results solely in minor reduction in the velocities of waves propagating in the flow plane at high angle to the flow direction.

\section{Discussion}

The present study highlights multiple evidence for modification of the modal composition and mineral chemistry due to interaction between the peridotites composing the Pacific plate and percolating melts. It also documents a variability in microstructure and, to a lesser extent, in olivine and pyroxenes CPO symmetry and intensity. The two processes are generally coupled, although there is no one-to-one relation between composition and microstructure.

\subsection{Changes in Modal and Mineral Composition Due to Interaction With Plume-Related Melts}

Most studied peridotites, in particular those with coarse-granular, partially recrystallized, or equigranular microstructures, show enrichment in orthopyroxene or clinopyroxene relative to model peridotite melting trends, suggesting refertilization (Figures 2 and 8a). The interstitial shapes of orthopyroxene and clinopyroxene (Figures 3, 5, 6, and 7) and the lack of correlation between the pyroxenes and the olivine CPOs in many samples (Figure 12) point to crystallization of pyroxenes from a melt after the last main deformation episode that affected this mantle section. Reactive percolation and partial crystallization of basaltic melts, in particular in the lower part of the lithospheric mantle (50- to 70-km depth) beneath Oahu, is also recorded by the relatively common occurrence of spinel- and garnet-bearing pyroxenites among Salt Lake xenoliths (Keshav et al., 2007; Sen, 1988; Sen et al., 1993). Evidence for reactive melt percolation leading to dunitization is less common (Figure 2), but a few olivine-rich harzburgites and dunites with coarse-granular, partially recrystallized, or equigranular microstructures are present among the studied peridotites (Table 1).

The marked variations in mineral chemistry among samples and, in a lesser extent, within samples (Figure 8) indicate that reactive melt percolation is spatially heterogeneous. This conclusion is consistent with previous petrological and geochemical studies that inferred spatially heterogeneous metasomatism (Bizimis et al., 2003; Ducea et al., 2002; Goto \& Yokoyama, 1988; Sen, 1988; Sen et al., 1993). Independent of the melt-rock reaction type (refertilization or dunitization), reactive melt percolation produced decrease in the Mg\# in most studied peridotites (Figures 8a to 8c). Increase in Mg\# is solely observed in rare coarse-granular and recrystallized peridotites. Ti enrichment, due either to increase in the clinopyroxene modal content (further evidence for refertilization) or increase in the Ti content of both clinopyroxene and spinel, is also recorded in many samples, in particular in those with coarse-granular or recrystallized microstructures (Figure 8d). However, Ti and Fe enrichments are not correlated, implying that the composition of the percolating melts varied in space and, probably, time. Variations in chemical conditions through time are, for instance, recorded by the particular microstructure of dunite PAL8, which displays a few oxidized olivine porphyroclasts overgrown by non-oxidized olivine neoblasts (Figures 7c and 7d), indicating a decrease in oxygen activity. Trace element data for orthopyroxene and clinopyroxene of the Oahu peridotites (Figure 9) record interactions with alkaline basalts, probably genetically linked to the rejuvenated-stage Honolulu volcanics (Bizimis et al., 2003). The composition of the reacting melt varied in space and time depending on the degree of melt-mantle interaction and reactions along the percolation path. Partially recrystallized and coarse-granular peridotites tend to display more metasomatized REE patterns than coarse-porphyroclastic peridotites, and the most reacted pyroxenes are observed in the equigranular peridotite (Figure 9d).

\subsection{Changes in the Microstructures and CPO: Melt-Triggered Recrystallization?}

The different microstructures among the Hawaii peridotites were interpreted by Mercier and Nicolas (1975) as recording a gradient in finite strain. In their interpretation, the coarse-granular peridotites represent undeformed rocks and the porphyroclastic, partially recrystallized, and equigranular microstructures record different stages of a heterogeneously distributed deformation. In this view, the stronger compositional changes observed in partially recrystallized and equigranular would point to melt focusing by the deformation. However, the present study documents a series of observations that do not fit this interpretation.

The coarse-granular peridotites have strong olivine CPO (Figures 12 and 13). This implies that they have been deformed and, subsequently, extensively annealed (recrystallized under static conditions). Grain boundary migration during annealing would result in effective decrease in the dislocation density and 
decrease in the grain boundary sinuosity, consistent with the low mean intragranular misorientations and shape factors of olivine in the coarse-granular peridotites (Figure 4). The high pyroxene modal contents, the marked yet variable enrichments of Ti and REE in pyroxenes, the highly fractionated trace element patterns with a strong melt-rock interaction signature (Figures 2, 8, and 9), the shapes of the pyroxenes (Figures 3 and 5), and the limited correlation between pyroxenes and olivine CPOs (Figure 12) in these peridotites point to annealing in presence of melts, which acted as fast diffusion paths.

A close analysis of the partially recrystallized and equigranular microstructures highlights that the spatial distribution of the neoblasts differs from the one usually observed in peridotite mylonites formed in both dry or melt or fluid-present conditions (e.g., Dijkstra et al., 2001; Frets et al., 2014; Hidas et al., 2016). The neoblasts are not concentrated in planes or anastomosed surfaces materializing a foliation, but heterogeneously dispersed along the porphyroclasts grain boundaries, forming irregularly shaped recrystallized pockets, or concentrated in vein-like structures oblique to the coarse-porphyroclastic foliation (Figures 3e to $3 \mathrm{~h}, 6$, and $\mathrm{S} 1$ ).

Based on the modal, microstructural, and chemical evidence for melt-rock reaction displayed by the partially recrystallized and equigranular peridotites (Figures 2-9), we propose therefore an alternative interpretation, where the coarse-porphyroclastic microstructures and olivine CPO represent the original microstructure of the Pacific plate mantle lithosphere. Upon the plume impact, reactive percolation of multiple melt batches triggered spatially heterogeneous static recrystallization within the lithospheric mantle, producing the partially recrystallized, equigranular, and coarse-granular microstructures. This interpretation, which we detail below, is consistent with the lack of evidence for any major viscoplastic deformation of the plate in response to the plume activity (which only produced elastic flexural deformation; Ribe \& Christensen, 1994; Wessel, 1993).

Coarse-porphyroclastic microstructures, characterized by a continuous grain size distribution with plurimillimetric olivine porphyroclasts with well-developed, widely spaced straight subgrain boundaries normal to the grains' elongation and interpenetrating grain boundaries (Figures 3, 4, and 5), are typical of deformation at high-temperature, low-stress conditions, followed by incomplete annealing (Nicolas \& Poirier, 1976). In an oceanic environment, they might have formed in response to asthenospheric flow by horizontal shearing due to a gradient in velocity between the plate and the underlying mantle and have been progressively frozen in the lithospheric mantle due to plate cooling and thickening (Harding-Hearn et al., 1997; Rümpker et al., 1999; Tommasi, 1998; Tommasi et al., 1996). Partial annealing would occur during the cooling stage; its intensity should therefore increase with depth (longer time at high temperature). Consistently, coarse-porphyroclastic microstructures also predominate among mantle xenoliths from French Polynesia and Ontong Java in the Pacific and from the Canaries and Fernando de Noronha in the Atlantic (Liu et al., 2019; Tommasi et al., 2004; Tommasi \& Ishikawa, 2014; Vonlanthen et al., 2006).

The partially recrystallized microstructures result from growth of strain-free neoblasts onto the coarse-porphyroclastic microstructure (Figures $3 \mathrm{e}$ to $3 \mathrm{~h}$ and 6). Full evolution of the process produced fine-grained polygonal or tabular equigranular microstructures (Figures $3 \mathrm{i}$ to $3 \mathrm{j}$ and 7 ). Recrystallization may occur during deformation (dynamic recrystallization) or after, during annealing (static recrystallization). As discussed above, the spatial distribution of the neoblasts is not consistent with dynamic recrystallization. The observed heterogeneous spatial distribution of the recrystallized fraction and the coexistence of a sinuous recrystallization front with polygonal neoblast-neoblast contacts (Figures 6, 7, and S2) are typical of the first stages of static recrystallization, where the nucleation and growth of neoblasts is controlled by the spatial gradients in density dislocation inherited from the preceding deformation (Lopez-Sanchez et al., 2020). Reactive melt percolation may have favored this process by producing partial dissolution and neocrystallization of olivine and pyroxenes and enhancing grain boundary migration. These processes are best recorded in those samples where recrystallization is concentrated in vein-like domains (Figures $3 \mathrm{~g}, 3 \mathrm{~h}, 6 \mathrm{a}$, and $6 \mathrm{~b}$ ), but peridotites with distributed recrystallization also often show a clear spatial association between pyroxene enrichment and recrystallization (Figure S1). Similar partial recrystallization of initially coarse-porphyroclastic microstructures has been described in peridotite xenoliths from Fernando de Noronha Island in the Equatorial Atlantic (Liu et al., 2019). In the latter, decrease in Mg\# and Ni content and increase in Ca content in olivine limited to a vein-like recrystallized domain has been documented, corroborating the role of reactive melt transport in the development of the recrystallized domains. The 
tablet-like euhedral shapes of the olivine neoblasts in strongly recrystallized samples (Figures $6 f$ and 7 ) further point to the presence of films of fluids or melts along grain boundaries during growth (Drury \& Van Roermund, 1989). Finally, all dunites and wehrlites, which are rocks produced by extensive melt-rock reaction, show equigranular microstructures (Table 1, Figure 7c). A major role of the melts on recrystallization might explain the lack of correlation between recrystallized fraction and recrystallized grain sizes with the equilibrium temperatures (Figure 10).

In our interpretation, the three microstructures: partially-recrystallized, equigranular, and coarse-granular, formed at the expense of the coarse-porphyroclastic peridotites by melt-assisted static recrystallization. The difference is that in the coarse-granular peridotites recovery and grain growth largely dominated nucleation. An open question is why one process - static recrystallization triggered by reactive melt percolation-produced two different microstructural evolutions. We may speculate, based on the on average higher equilibrium temperatures of the coarse-grained peridotites (Figure 10), that these samples were already more annealed and had a lower density of possible nucleation sites allowing for the formation of neoblasts and/or that the higher temperatures allowed for more extensive annealing.

In summary, we interpret the coarse-porphyroclastic microstructures and olivine CPO as the original microstructure of the Pacific plate mantle lithosphere. Plume-related reactive melt percolation produced spatially heterogeneous changes in the microstructure following two paths: (1) dissolution and neocrystallization of olivine and pyroxenes and fluid-assisted grain boundary migration producing the fine-grained strain-free neoblasts that characterize the partially recrystallized and equigranular microstructures and (2) annealing dominated by grain coarsening, which produced the coarse-granular microstructures. However, there is no simple relation between microstructure and chemical or modal composition within the Hawaiian peridotites. This is consistent with a time-cumulated record of reactive melt percolation processes that were heterogeneous both in space and time.

The changes in microstructure are associated with moderate variations in the olivine CPO (Figures 12, 13, S2, and S3). Coarse-granular and coarse-porphyroclastic peridotites show dominantly strong orthorhombic to axial-[100] olivine CPO, with [100] aligned in the lineation and [010] normal to the foliation. We interpret these CPOs as representative of the original oceanic lithosphere fabric, formed by dislocation creep at the lithosphere-asthenosphere limit at high-temperature, low-stress conditions, with dominant activation of the [100](010) slip system in olivine, and progressively frozen by plate cooling. Annealing dominated by grain growth changed locally the microstructures to coarse-granular, but did not modify significantly neither the strength nor the symmetry of the olivine CPO. In contrast, nucleation during static recrystallization produced dispersion of the olivine $\mathrm{CPO}$ and sometimes changed the pattern to more axial-[010] (Figures 13 and S3). Strongly recrystallized $(>25 \%)$ and equigranular peridotites have on average weaker olivine CPO. However, as for the changes in chemical composition, there is no one-to-one relation between recrystallization intensity and olivine CPO strength (Figure 13b). The limited dispersion and strong inheritance relation of the olivine CPO in many partially recrystallized peridotites (Figure S4) may be explained by the fact that refertilization-type melt-rock reactions are more common than dunitization ones. In this context, little olivine is neoformed and grain size reduction probably largely results from fragmentation of the porphyroclasts with preferential dissolution along crystalline defects, like subgrain walls (e.g., Nicolas et al., 1973; Soustelle et al., 2010). Thus, most olivine neoblasts inherit, with some dispersion, the orientation of their parent grain (Figure S2). In contrast, as previously observed in French Polynesia (Tommasi et al., 2004), dunites and wehrlites, where neocrystallization of olivine was important, show very weak olivine CPO (Figure 13a).

\subsection{Spatial Representativeness of the Observations}

Which is the spatial representativeness of the present observations? Xenolith sampling is by essence punctual, non-controlled, and probably spatially biased towards the proximity of dykes. It samples, nevertheless, rocks that actually compose the lithospheric mantle beneath Hawaii. Fe enrichment leading to bulk rock Mg\# $<88$ (Figure $8 \mathrm{a}$ ) or dunitization may only be produced in presence of very high melt-rock ratios (Bodinier \& Godard, 2014), suggesting that such peridotites might represent reacted wall rock of veins or dykes. The most extreme changes in composition are therefore probably local and do not affect large volumes of the lithospheric mantle beneath Hawaii. Another evidence for extremely localized microstructural (and compositional) changes are the vein-like millimeter-scale recrystallization domains (Figures 3e, 3h, and 6a). However, most peridotites studied here display rather homogeneous compositions and 
microstructures at the thin section scale. This suggests that the observed changes are associated with percolation of melts along grain boundaries (porous flow), which may have promoted moderate changes in both composition and microstructures over significant volumes of the lithospheric mantle beneath the islands, though these changes will be spatially heterogeneous as the composition and volumes of melts will vary through space and time.

The similarity of the observations in xenoliths from the four localities corroborates that similar processes took place in the mantle lithosphere beneath at least three different Hawaii islands. The most obvious candidate for producing the compositional and microstructural changes documented here is the extensive magmatism that formed the islands. This might imply that the changes may be more important just beneath the islands. However, melt production occurs over a large domain and the way melts are focused towards the volcanoes is still poorly constrained. Thus, changes in composition, microstructure, and CPO like those described here may affect rather large volumes of the lithospheric mantle beneath the swell. A way of testing this hypothesis is to compare the seismic properties calculated for the peridotites to seismological observations.

\subsection{Consequences to Seismic Properties}

Seismic velocities depend on the rock composition and CPO, as well as on the pressure and temperature conditions. Seismic anisotropy, on the other hand, only weakly depends on temperature and pressure. Thermometry data on spinel peridotites do not allow constraining the geothermal gradient beneath the islands, since precise constraints on equilibrium depths are not available. The equilibrium temperatures of the peridotites are consistent with both a "normal" geotherm for a $90 \mathrm{~km}$ thick oceanic plate and hotter geotherms (Figure 11). Thermobarometric data on spinel- and garnet-bearing pyroxenites imply limited $\left(100^{\circ} \mathrm{C}\right)$ heating of the lower lithosphere (Figure 11). However, we cannot constrain whether these higher temperatures are local transient anomalies, associated with melt transport and crystallization (latent heat), or if they record a regionally hotter geotherm. The average Hawaii seismic properties presented in Figure 15 were calculated considering the equilibrium temperature and pressure of the spinel- and garnet-bearing pyroxenite SAL33 $\left(1000^{\circ} \mathrm{C}, 1.45 \mathrm{GPa}\right)$. They represent estimates for the seismic velocities at $\sim 45-\mathrm{km}$ depth calculated under the assumption that the pyroxenites equilibration conditions are representative of regional heating of the base of the lithosphere due to the plume activity. This assumption is consistent with recent models of plate flexure beneath the Hawaiian ridge, which best adjust gravity and bathymetry data when moderate reheating of the lithosphere is assumed (Pleus et al., 2020).

To estimate the possible velocity reduction associated with this lithospheric heating, we also calculated average seismic properties for temperatures $\left(900^{\circ} \mathrm{C}\right)$ predicted at the same depth by a plume-lithosphere interaction model, which does not consider advective heating by melts and, by consequence, does not predict any lithospheric heating at depths $<50 \mathrm{~km}$ (Figure 11). The increase in temperature by $100^{\circ} \mathrm{C}$ decreases $P$ and $S$ wave velocities by $<1 \%$, if anelastic effects are not considered (Table 3). Anelasticity might result in higher seismic velocity reduction for a given temperature anomaly (Jackson \& Faul, 2010), in particular for long period waves, since the velocity reduction is proportional to the integral of the attenuation at all frequencies above the considered frequency (Takei, 2017). This could explain, for instance, that tomographic models based solely on surface waves data (Laske et al., 2011) image stronger velocity anomalies than those combining multiple data types (Cheng et al., 2015). However, at temperatures below $1200^{\circ} \mathrm{C}$, anelasticity effects should be small (Takei, 2017). Anelastic effects may therefore be important during melt percolation episodes, but negligible after extraction or crystallization of the melts.

How do the predicted seismic velocities compare to observations in the Hawaii swell region? Laske et al. (2011) performed both path-averaged 1D dispersion profiles and full tomographic inversion of Rayleigh waves. Path-averaged seismic velocities $<4 \mathrm{~km} / \mathrm{s}$ are predicted for most paths within the swell at frequencies of $50 \mathrm{mHz}$, which are sensitive to depths of $20-70 \mathrm{~km}$. These values are significantly lower than the average Vs $(4.5 \mathrm{~km} / \mathrm{s}$, Table 3 ) or even the minimum Vs2 predicted for the average Oahu peridotite at $45-\mathrm{km}$ depth using the hot geotherm $(4.3 \mathrm{~km} / \mathrm{s}$, Figure 15). Average Rayleigh wave velocities predicted by the tomographic model at 40- to $60-\mathrm{km}$ depth beneath the swell are, nevertheless, closer to those predicted based on the xenoliths data, though multiple spots with stronger negative anomalies, indicative of lower velocities (down to $4.3 \mathrm{~km} / \mathrm{s}$ ), are present in the tomographic model at these depths (cf. Figure 1 for the 40-km depth slice). Fe enrichment of olivine, which has not been considered in the calculation of the average seismic 
properties of the Hawaii peridotites because the average olivine $\mathrm{Mg \#}$ in the presently studied samples is 89.2, may further decrease seismic velocities. However, to explain the strongest negative velocity anomalies observed at lithospheric depths in Rayleigh wave tomography models (up to $-3 \%$, Figure 1; Laske et al., 2011), Mg\# in olivine should be as low as 85-86 (Tommasi et al., 2004). Such values are only observed in two samples (Figure 8a) and may solely be achieved by interaction with high volumes of melts, probably at the wall rock of dykes (Bodinier \& Godard, 2014). This process cannot possibly explain the tens of kilometers wide anomalies of the Rayleigh wave tomographic model.

Presence of fluids may also decrease seismic velocities. However, the high resistivity of the lithosphere beneath the swell indicates that if fluids or melts are present, connectivity and hence fluid or melt fractions should be low (Constable \& Heinson, 2004). We do not have therefore reasonable petrophysical explanations for the most extreme negative velocity anomalies in the Rayleigh wave tomographic model (Laske et al., 2011). More recent tomographic models, which combine body waves, surface waves, and ambient noise, image weaker negative velocity anomalies at lithospheric depths beneath the Hawaii swell $(<-2 \%)$, which are best expressed at depths $>50 \mathrm{~km}$ (Cheng et al., 2015). These observations might be explained by the association of limited Fe enrichment due to reactive melt percolation through the lithosphere (Figure 8a) and moderate heating of the base of the lithosphere in response to the plume activity (Figure 11), suggesting that both phenomena affected volumes large enough to be mapped by geophysical observations.

Refraction data provide constraints on the $P$ wave velocities and anisotropy in the shallowmost lithospheric mantle beneath the northeastern Hawaii Arch, north of Oahu and Kauai. $P$ wave velocities vary strongly as a function of the orientation of the line, from $8.45 \mathrm{~km} / \mathrm{s}$ in E-W lines to $7.85 \mathrm{~km} / \mathrm{s}$ in N-S lines, indicating an azimuthal anisotropy of 7.4\% (Morris et al., 1969b). More recently, slightly higher $P$ wave velocities $(8.5-8.65$ and $7.9-8 \mathrm{~km} / \mathrm{s}$ ) were observed parallel and normal to the paleospreading direction, respectively (Ohira et al., 2018). The anisotropy observed in both studies is consistent with the one predicted for the average Oahu peridotite at 45-km depth (Figure 15). The observed velocities are higher, but they are consistent with those predicted for the average Oahu peridotite for a temperature of $230^{\circ} \mathrm{C}$ and a pressure of $0.28 \mathrm{GPa}$, expected at depths of $10 \mathrm{~km}\left(\mathrm{Vp}_{\max }=8.61 \mathrm{~km} / \mathrm{s}\right.$ and $\left.\mathrm{Vp}_{\min }=7.92 \mathrm{~km} / \mathrm{s}\right)$, corroborating the absence of any thermal anomaly at sub-Moho depths.

Teleseismic $S$ wave splitting patterns within the Hawaii swell are complex, displaying sharp variations in both fast polarization orientation and delay times, which are often $<1 \mathrm{~s}$ (Collins et al., 2012). The present study, together with the $P$ wave anisotropy detected by refraction profiles and with Rayleigh wave azimuthal anisotropy at short periods (Laske, 2018), implies that the lithospheric mantle in the region retained a rather strong seismic anisotropy, acquired by progressive freezing of olivine CPO formed by horizontal shearing in the asthenosphere in response to a gradient in velocity between the plate and the convective mantle. Vertically propagating teleseismic $S$ waves should therefore sample an intrinsic polarization anisotropy of $\sim 3 \%$ and cumulate a delay time of $0.55 \mathrm{~s}$ in a $70 \mathrm{~km}$ thick lithosphere, developing a fast $S$ wave polarization intermediate between the paleospreading direction and the Pacific absolute plate motion, that is, close to EW. Anisotropy due to olivine CPO formed in the asthenosphere due to plume-related flow should add to this signal. The variability in the $S$ wave splitting patterns and the rather low delay times within the Hawaii swell imply therefore a strong variability in flow directions within the plume-fed asthenosphere, probably due to small-scale convection within it (Agrusta et al., 2013, 2015; Ballmer et al., 2011, 2013). This conclusion is corroborated by Rayleigh wave azimuthal anisotropy, which shows a disturbed pattern close to the Hawaiian islands at long periods, but fast propagation directions aligned with the absolute plate motion at short periods (Laske, 2018).

\section{Conclusions}

Petrophysical analyses of 48 spinel peridotites and three pyroxenites from four localities in three Hawaiian islands (Salt Lake and Pali in Oahu, Grove Farm in Kauai, and Pu'uwai in Nihau) highlight that reactive transport of plume-related melts has modified the composition, microstructures, and CPO of the Pacific mantle lithosphere. Petrological evidences for this process are (1) modal compositions that significantly deviate from partial melting trends, most often by enrichment in pyroxenes; (2) interstitial shapes of pyroxenes; 


\section{Acknowledgments}

A. Nicolas, deceased 31 March 2020, provided the xenoliths. We would like to dedicate this article to this exceptional researcher, who set the basis of the petrophysical study of mantle deformation. Whitney Behr and Ioannis Baziotis are thanked for their thoughtful reviews and Alain Vauchez for discussions on the interpretation of the recrystallization microstructures. Laetitia Peltier and Sebastien Granet performed a first set of one-point per grain EBSD measurements and microprobe analyses and Stéphanie Lauvaure LA-ICPMS analyses as part of their master research projects at the Université de Montpellier; this early data acquisition was funded by the program DyETI (2004-2006) of the Institut National des Sciences de l'Univers (INSU) du Centre National de la Recherche (CNRS), FR. D. Mainprice provided macros for analyzing the EBSD data and calculating seismic properties using the OpenSource library MTEX. C. Nevado and D. Delmas prepared high-quality polished thin sections for EBSD measurements. EBSD analyses were performed with the help of F. Barou at the INSU EBSD-SEM national facility at Geosciences Montpellier. Electron microprobe analyses were carried out with the help of B. Boyer and C. Merlet. L. M. participation to this project was funded by the "Science without Borders" program of the Brazilian government (call 2014-2015).
(3) Fe enrichment in olivine and pyroxenes and/or (4) Ti enrichment in clinopyroxene and spinels; and (5) variable enrichment of LREE in clinopyroxene and, to a lesser extent, in orthopyroxene.

Coarse-porphyroclastic microstructures and strong orthorhombic to axial-[100] olivine CPO predominate. They probably represent the original Pacific plate microstructures and $\mathrm{CPO}$, formed by shearing at the base of the plate and frozen into the plate as the latter cooled and thickened. However, these coarse-porphyroclastic microstructures are often overprinted by variable volumes of fine-grained aggregates of polygonal olivine and pyroxenes, which occur either in diffuse vein-like structures or irregular seams along grain boundaries and locally replace almost entirely the initial coarse-porphyroclastic microstructure. Based on the spatial distribution and polymineralic nature of the recrystallized domains, on the pyroxene enrichment as well as Fe, Ti, and LREE enrichments in clinopyroxenes displayed by most partially recrystallized and equigranular peridotites, we interpret this recrystallization as produced by partial dissolution and neocrystallization of olivine and pyroxenes during reactive melt percolation and melt-favored grain boundary migration, rather than by viscoplastic deformation. This process resulted in moderate dispersion of the olivine CPO and locally produced axial-[010] olivine CPO. A few peridotites show coarse-granular, well-annealed microstructures, but strong olivine CPO. Based on the similar equilibrium temperatures and strong enrichment in $\mathrm{Ti}$ in both pyroxenes relative to other microstructural types and on their REE patterns, we interpret the annealing producing the coarse-granular microstructures also as favored by the presence of melts.

However, there is no simple relation between modal or chemical compositions and microstructures. This is probably due to the highly heterogeneous nature of the reactive melt percolation in both time and space and to variations in the percolating melts composition. Similar variability in compositions, microstructures, and $\mathrm{CPO}$ beneath three different islands indicates, nevertheless, that these processes occurred beneath all major shield volcanoes. Seismic tomography models show a heterogeneous but widespread reduction of seismic velocities in the lower section of the lithospheric mantle beneath the swell. Moderate heating of the base of the lithosphere, suggested by thermobarometric data for the garnet-pyroxenites, and limited Fe enrichment in olivine, observed in many peridotites, may account for up to $2 \%$ of reduction in seismic velocity, partially explaining the low-velocity anomalies observed in the deep lithospheric mantle beneath the swell (Cheng et al., 2015; Laske et al., 2011).

Despite the changes in composition and microstructure, the studied Hawaii peridotites preserved olivine CPO typical of the lithosphere in a fast-moving oceanic plate. This conclusion is consistent with the strong azimuthal anisotropy of $P$ waves recorded by refraction data (Morris et al., 1969b; Ohira et al., 2018) and with the fast propagation parallel to the fossil plate motion recorded by short-period Rayleigh waves (Laske, 2018). If the lithosphere preserves a "normal" oceanic lithosphere seismic anisotropy pattern, the spatial variability in both splitting directions and delay time and rather low delay times $(<1 \mathrm{~s})$ displayed by split teleseismic shear waves (Collins et al., 2012) should record variations in flow directions due to small-scale convection in the plume-fed asthenosphere.

\section{Data Availability Statement}

The CPO data on which the results of this work are based are available at the Zenodo Open AIRE repository under doi 10.5281/zenodo.3754078.

\section{References}

Abramson, E. H., Brown, M., Slutsky, L. J., \& Zaug, J. (1997). The elastic constants of San Carlos olivine up to 17 GPa. Journal of Geophysical Research, 102, 12,252-12,263.

Agrusta, R., Arcay, D., Tommasi, A., Davaille, A., Ribe, N., \& Gerya, T. (2013). Small-scale convection in a plume-fed low viscosity layer beneath a moving plate. Geophysical Journal International, 194, 591-610. https://doi.org/10.1093/gji/ggt128

Agrusta, R., Tommasi, A., Arcay, D., Gonzalez, A., \& Gerya, T. (2015). How partial melting affects small-scale convection in a plume-fed sublithospheric layer beneath fast-moving plates. Geochemistry, Geophysics, Geosystems, 16, 3924-3945. https://doi:10.1002/ 2015GC005967

Arai, S. (1994). Characterization of spinel peridotites by olivine-spinel compositional relationships: Review and interpretation. Chemical Geology, 113, 191-204.

Bachmann, F., Hielcher, R., \& Schaeben, H. (2011). Grain detection from 2D and 3D EBSD data-Specification of the MTEX algorithm. Ultramicroscopy, 11, 1720-1733.

Ballmer, M. D., Ito, G., Van Hunen, J., \& Tackley, P. J. (2011). Spatial and temporal variability in Hawaiian hotspot volcanism induced by small-scale convection. Nature Geoscience, 4, 457. 
Ballmer, M. D., Ito, G., Wolfe, C. J., \& Solomon, S. C. (2013). Double layering of a thermochemical plume in the upper mantle beneath Hawaii. Earth and Planetary Science Letters, 376, 155-164.

Bizimis, M., Griselin, M., Lassiter, J. C., Salters, V. J., \& Sen, G. (2007). Ancient recycled mantle lithosphere in the Hawaiian plume: Osmium-hafnium isotopic evidence from peridotite mantle xenoliths. Earth and Planetary Science Letters, 257, 259-273. https://doi.org/ 10.1016/j.epsl.2007.02.036

Bizimis, M., Sen, G., \& Salters, V. J. (2003). Hf-Nd isotope decoupling in the oceanic lithosphere: Constraints from spinel peridotites from Oahu. Earth and Planetary Science Letters, 217, 43-58.

Bodinier, J.-L., \& Godard, M. (2014). Orogenic, ophiolitic and abyssal peridotites. Treatise on Geochemistry (2nd edition), 3: The Mantle and Core, 103-167.

Brey, G. P., \& Koehler, T. (1990). Geothermobarometry in four-phase lherzolites; II, new thermobarometers, and practical assessment of existing thermobarometers. Journal of Petrology, 31(6), 1353-1378.

Cadio, C., Ballmer, M. D., Panet, I., Diament, M., \& Ribe, N. (2012). New constraints on the origin of the Hawaiian swell from wavelet analysis of the geoid to topography ratio. Earth and Planetary Science Letters, 359, 40-54.

Chai, M., Brown, J. M., \& Slutsky, L. J. (1997a). The elastic constants of an aluminous orthopyroxene to 12.5 GPa. Journal of Geophysical Research, 102, 14,779-14,786.

Chai, M., Brown, J. M., \& Slutsky, L. J. (1997b). The elastic constants of a pyrope-grossular-almandine garnet up to 20 GPa. Geophysical Research Letters, 24(5), 523-526.

Cheng, C., Allen, R. M., Porritt, R. W., \& Ballmer, M. D. (2015). Seismic constraints on a double-layered asymmetric whole-mantle plume beneath Hawaii. In R. Carey, V. R. Cayol, M. Poland, \& D. Weis (Eds.), Hawaiian Volcanos: From Source to Surface (Vol. 208, pp. 19-34). Washington DC: AGU Geophys. Monograph.

Collins, J. A., Wolfe, C. J., \& Laske, G. (2012). Shear wave splitting at the Hawaiian hot spot from the plume land and ocean bottom seismometer deployments. Geochemistry, Geophysics, Geosystems, 13, Q02007. https://doi.org/10.1029/2011GC003881

Collins, M. D., \& Brown, J. M. (1998). Elasticity of an upper mantle clinopyroxene. Physics and chemistry of minerals, 26, 7-13.

Constable, S., \& Heinson, G. (2004). Hawaiian hot-spot swell structure from seafloor MT sounding. Tectonophysics, 389, $111-124$.

Cousens, B. L., \& Clague, D. A. (2015). Shield to rejuvenated stage volcanism on Kauai and Niihau, Hawaiian islands. Journal of Petrology, $56,1547-1584$.

Demouchy, S., Tommasi, A., Ionov, D., Higgie, K., \& Carlson, R. (2019). Microstructures, water contents, and seismic properties of the mantle lithosphere beneath the northern limit of the Hangay Dome, Mongolia. Geochemistry, Geophysics, Geosystems, $20,183-207$. https://doi:10.1029/2018GC007931

D'Errico, M. E., Warren, J. M., \& Godard, M. (2016). Evidence for chemically heterogeneous Arctic mantle beneath the Gakkel Ridge. Geochimica et Cosmochimica Acta, 174, 291-312.

Dijkstra, A. H., Drury, M. R., \& Vissers, R. L. (2001). Structural petrology of plagioclase peridotites in the West Othris Mountains (Greece): Melt impregnation in mantle lithosphere. Journal of Petrology, 42, 5-24.

Drouin, M., Godard, M., Ildefonse, B., Bruguier, O., \& Garrido, C. (2009). In situ geochemistry of olivine-rich troctolites (IODP Hole U1309D, Atlantis Massif, Mid-Atlantic Ridge, $30^{\circ} \mathrm{N}$ ): A record of magmatic impregnation in the lower oceanic lithosphere. Chemical Geology, 264, 71-88.

Drury, M. R., \& Van Roermund, H. M. L. (1989). Fluid-assisted recrystallization in upper mantle peridotite xenoltihs from kimberlites. Journal of Petrology, 30, 133-152.

Ducea, M., Sen, G., Eiler, J. M., \& Fimbres, J. (2002). Melt depletion and subsequent metasomatism in the shallow mantle beneath Koolau volcano, Oahu (Hawaii). Geochemistry, Geophysics, Geosystems, 3(2), 1015. https://doi.org/10.1029/2001GC000184

Frets, E. C., Tommasi, A., Garrido, C. J., Vauchez, A., Mainprice, D., Targuisti, K., \& Amri, I. (2014). The Beni Bousera Peridotite (Rif Belt, Morocco): An oblique-slip low-angle shear zone thinning the subcontinental mantle lithosphere. Journal of Petrology, 55, 283-313.

Goto, A., \& Yokoyama, K. (1988). Lherzolite inclusions in olivine nephelinite tuff from Salt Lake Crater, Hawaii. Lithos, 21 , 67-80.

Harding-Hearn, E., Humphreys, E. D., Chai, M., \& Brown, J. M. (1997). Effect of anisotropy on oceanic upper mantle temperatures, structure, and dynamics. Journal of Geophysical Research, 102, 11,943-11,956.

Hidas, K., Tommasi, A., Garrido, C. J., Padrón-Navarta, J. A., Mainprice, D., Vauchez, A., et al. (2016). Fluid-assisted strain localization in the shallow subcontinental lithospheric mantle. Lithos, 262, 636-650.

Hielscher, R., \& Schaeben, H. (2008). A novel pole figure inversion method: Specification of the MTEX algorithm. Journal of Applied Crystallography, 41, 1024-1037. https://doi.org/10.1107/S0021889808030112

Jackson, E. D., \& Wright, T. L. (1970). Xenoliths in the Honolulu volcanic series, Hawaii. Journal of Petrology, 11, 405-433.

Jackson, I., \& Faul, U. H. (2010). Grain size-sensitive viscoelastic relaxation in olivine: Towards a robust laboratory-based model for seismological application. Physics of the Earth and Planetary Interiors, 183, 151-163.

Kelemen, P. B., \& Dick, H. J. B. (1995). Focused melt flow and localized deformation in the upper mantle; juxtaposition of replacive dunite and ductile shear zones in the Josephine Peridotite, SW Oregon. Journal of Geophysical Research, 100, 423-438.

Keshav, S., Sen, G., \& Presnall, D. C. (2007). Garnet-bearing xenoliths from Salt Lake Crater, Oahu, Hawaii: High-pressure fractional crystallization in the oceanic mantle. Journal of Petrology, 48, 1681-1724.

$\mathrm{Klemme}$, S. (2004). The influence of $\mathrm{Cr}$ on the garnet-spinel transition in the Earth's mantle: Experiments in the system $\mathrm{MgO}-\mathrm{Cr} 2 \mathrm{O} 3-\mathrm{SiO} 2$ and thermodynamic modelling. Lithos, 77, 639-646.

Laske, G. (2018). Anomalous azimuthal anisotropy near Hawaii-Plume-perturbed mantle flow? Geophysical Research Abstracts, 20, EGU2018-EGU2303.

Laske, G., Markee, A., Orcutt, J. A., Wolfe, C. J., Collins, J. A., Solomon, S. C., et al. (2011). Asymmetric shallow mantle structure beneath the Hawaiian swell: Evidence from Rayleigh waves recorded by the PLUME network. Geophysical Journal International, 187, 1725-1742.

Le Roux, V., Bodinier, J. L., Tommasi, A., Alard, O., Dautria, J. M., Vauchez, A., \& Riches, A. (2007). The Lherz spinel-lherzolite: refertilized rather than pristine mantle. Earth and Planetary Science Letters, 259, 599-612. https://doi.org/10.1016/j.epsl.2007.1005.1026

Li, Y., Kind, R., Yuan, X., Wolbern, I., \& Hanka, W. (2004). Rejuvenation of the lithosphere by the Hawaiian plume. Nature, 427, 827-829. https://doi.org/10.1038/nature02349

Lissenberg, C. J., \& Dick, H. J. B. (2008). Melt-rock reaction in the lower oceanic crust and its implications for the genesis of mid-ocean ridge basalt. Earth and Planetary Science Letters, 27, 311-325.

Liu, S., Tommasi, A., Vauchez, A., \& Mazzucchelli, M. (2019). Deformation, annealing, melt-rock interaction, and seismic properties of an old domain of the equatorial Atlantic lithospheric mantle. Tectonics, 38, 1164-1188. https://doi.org/10.1029/2018TC005373 
Lopez-Sanchez, M. A., Tommasi, A., Barou, F., \& Quey, R. (2020). Dislocation-driven recrystallization in AZ31B magnesium alloy imaged by quasi-in-situ EBSD in annealing experiments. Materials Characterization, 165, 110,382. https://doi.org/10.1016/j. matchar.2020.110382

Mainprice, D. (1990). A FORTRAN program to calculate seismic anisotropy from the lattice preferred orientation of minerals. Computers \& Geosciences, 16, 385-393.

Mainprice, D., Bachmann, F., Hielcher, R., \& Schaeben, H. (2014). Descriptive tools for the analysis of texture projects with large datasets using MTEX - Strength, symmetry and components. In D. J. Prior, E. H. Rutter, D. J. Tatham (Eds.), Field experiment and theory: In honour of Ernest Rutter (Vol. 360, pp. 251-271). London: Geological Society, Special Publications. https://doi.org/10.1144/ sp360.10

Mainprice, D., Hielscher, R., \& Schaeben, H. (2014). Calculating anisotropic physical properties from texture data using the MTEX open-source package. In D. J. Prior, E. H. Rutter, D. J. Tatham (Eds.), Deformation mechanisms, rheology and tectonics: Microstructures, mechanics and anisotropy (Vol. 360, pp. 175-192). London: Geological Society, Special Publications. https://doi.org/10.1144/SP360.10

Mercier, J.-C., \& Nicolas, A. (1975). Textures and fabrics of upper mantle peridotites as illustrated by xenoliths from basalts. Journal of Petrology, 16, 454-487.

Moore, W. B., Schubert, G., \& Tackley, P. J. (1998). Three-dimensional simulations of plume-lithosphere interaction at the Hawaiian swell. Science, 279, 1008-1011.

Morgan, W. J. (1971). Convection plumes in the lower mantle. Nature, 230, 42-43.

Morris, G., Raitt, R., \& Shor, G. Jr. (1969a). Velocity anisotropy and delay-time maps of the mantle near Hawaii. Journal of Geophysical Research, 74, 4300-4316.

Morris, G. B., Raitt, R. W., \& Shor, G. G. Jr. (1969b). Velocity anisotropy and delay-time maps of the mantle near Hawaii. Journal of Geophysical Research, 74, 4300-4316.

Nickel, K. G., \& Green, D. H. (1985). Empirical geothermobarometry for garnet peridotites and implications for the nature of the lithosphere, kimberlites and diamonds. Earth and Planetary Science Letters, 73, 158-170.

Nicolas, A., Boudier, F., \& Boullier, A. M. (1973). Mechanism of flow in naturally and experimentally deformed peridotites. American Journal of Science, 273, 853-876. https://doi.org/10.2475/ajs.273.10.853

Nicolas, A., \& Poirier, J. P. (1976). Crystalline plasticity and solid state flow in metamorphic rocks. (p. 444). London: John Wiley \& Sons.

Ohira, A., Kodaira, S., Moore, G. F., Yamashita, M., Fujiwara, T., Kaiho, Y., et al. (2018). Active-source seismic survey on the northeastern Hawaiian Arch: Insights into crustal structure and mantle reflectors. Earth, Planets and Space, 70, 1-16. https://doi.org/10.1186/s40623018-0891-8

O'Neill, H. S. C. (1981). The transition between spinel lherzolite and garnet lherzolite, and its use as a geobarometer. Contributions to Mineralogy and Petrology, 77, 185-194.

Pearce, N. J. G., Perkins, W. T., Westgate, J. A., Gorto, M. P., Jackson, S. E., Neal, C. R., \& Chenery, S. P. (1997). A compilation of new and published major and trace element data for NIST SRM 610 and NIST SRM 612 glass reference materials. Geostandard Newsletters, 21, $115-144$.

Pleus, A., Ito, G., Wessel, P., \& Frazer, L. N. (2020). Rheology and thermal structure of the lithosphere beneath the Hawaiian Ridge inferred from gravity data and models of plate flexure. Geophysical Journal International, 222, 201-224. https://doi.org/10.1093/gji/ggaa155

Reichmann, H. J., \& Jacobsen, S. D. (2004). High-pressure elasticity of a natural magnetite crystal. American Mineralogist, 89, 1061-1066.

Ribe, N. M., \& Christensen, U. R. (1994). Three-dimensional modeling of plume-lithosphere interaction. Journal of Geophysical Research, 99, 669-682.

Ringwood, A. E. (1975). Composition and petrology of the Earth's mantle (p. 672). New York: McGraw-Hill.

Rümpker, G., Tommasi, A., \& Kendall, J.-M. (1999). Numerical simulations of depth-dependent anisotropy and frequency-dependent wave propagation effects. Journal of Geophysical Research, 104, 23,141-23,154.

Rychert, C. A., Laske, G., Harmon, N., \& Shearer, P. M. (2013). Seismic imaging of melt in a displaced Hawaiian plume. Nature Geoscience, $6,657$.

Sen, G. (1988). Petrogenesis of spinel lherzolite and pyroxenite suite xenoliths from the Koolau shield, Oahu, Hawaii: Implications for petrology of the post-eruptive lithosphere beneath Oahu. Contributions to Mineralogy and Petrology, 100, 61-91.

Sen, G., Frey, F. A., Shimizu, N., \& Leeman, W. P. (1993). Evolution of the lithosphere beneath Oahu, Hawaii: Rare Earth element abundances in mantle xenoliths. Earth and Planetary Science Letters, 119, 53-69. https://doi.org/10.1016/0012-821x(93)90006-u

Sen, G., Keshav, S., \& Bizimis, M. (2005). Hawaiian mantle xenoliths and magmas: Composition and thermal character of the lithosphere. American Mineralogist, 90, 871-887.

Soustelle, V., Tommasi, A., Demouchy, S., \& Ionov, D. (2010). Deformation and fluid-rock interactions in the supra-subduction mantle: Microstructures and water contents in peridotite xenoliths from the Avacha Volcano, Kamchatka. Journal of Petrology, 51, 363-394. https://doi.org/10.1093/petrology/egp1085

Sun, S. S., \& McDonough, W. F. (1989). Chemical and isotopic systematics of oceanic basalts: Implications for mantle composition and processes. In Magmatism in Ocean Basins, Special Publications (Vol. 42, pp. 313-345). London: Geological Society.

Takei, Y. (2017). Effects of partial melting on seismic velocity and attenuation: A new insight from experiments. Annual Review of Earth and Planetary Sciences, 45, 447-470.

Tommasi, A. (1998). Forward modeling of the development of seismic anisotropy in the upper mantle, Earth Planet Science Letters, 160, $1-13$.

Tommasi, A., Godard, M., Coromina, G., Dautria, J.-M., \& Barsczus, H. (2004). Seismic anisotropy and compositionally induced velocity anomalies in the lithosphere above mantle plumes: A petrological and microstructural study of mantle xenoliths from French Polynesia. Earth and Planetary Science Letters, 227, 539-556. https://doi.org/10.1016/j.epsl.2004.09.019

Tommasi, A., \& Ishikawa, A. (2014). Microstructures, composition, and seismic properties of the Ontong Java Plateau mantle root. Geochemistry, Geophysics, Geosystems, 15, 4547-4569. https://doi.org/10.1002/2014GC005452

Tommasi, A., \& Vauchez, A. (2015). Heterogeneity and anisotropy in the lithospheric mantle. Tectonophysics, 661, 11-37.

Tommasi, A., Vauchez, A., \& Russo, R. (1996). Seismic anisotropy in ocean basins: Resistive drag of sublithospheric mantle? Geophysical Research Letters, 23, 2991-2994.

Van Achterberg, E., Ryan, C. G., Jackson, S. E., \& Griffin, W. L. (2001). Laser ablation ICP-MS in the Earth Science: Principles and applications. In P. Sylvester (Ed.). Data reduction software for LA-ICP-MS (pp. 239-243). Quebec: Mineralogical Association of Canada.

Von Herzen, R., Cordery, M., Detrick, R., \& Fang, C. (1989). Heat flow and the thermal origin of hot spot swells: The Hawaiian swell revisited. Journal of Geophysical Research, 94, 13,783-13,799. 
Vonlanthen, P., Kunze, K., Burlini, L., \& Grobéty, B. (2006). Seismic properties of the upper mantle beneath Lanzarote (Canary Islands): Model predictions based on texture measurements by EBSD. Tectonophysics, 428, 65-86.

Warren, J. M. (2016). Global variations in abyssal peridotite compositions. Lithos, 248-251, 193-219. https://doi.org/10.1016/j. lithos.2015.12.023

Wessel, P. (1993). A reexamination of the flexural deformation beneath the Hawaiian islands. Journal of Geophysical Research, 98 , $12,177-12,910$

Witt-Eickschen, G., \& Seck, H. A. (1991). Solubility of Ca and Al in orthopyroxene from spinel peridotite: An improved version of an empirical geothermometer. Contributions to Mineralogy and Petrology, 106, 431-439. https://doi.org/10.1007/BF00321986

Wolfe, C. J., Solomon, S. C., Laske, G., Collins, J. A., Detrick, R. S., Orcutt, J. A., et al. (2009). Mantle shear-wave velocity structure beneath the Hawaiian hot spot. Science, 326, 1388-1390. https://doi.org/10.1126/science.1180165

Wolfe, C. J., Solomon, S. C., Laske, G., Collins, J. A., Detrick, R. S., Orcutt, J. A., et al. (2011). Mantle P-wave velocity structure beneath the Hawaiian hotspot. Earth and Planetary Science Letters, 303, 267-280. 